\title{
Impaired Hepatic Apolipoprotein B and E Translation in Streptozotocin Diabetic Rats
}

\author{
Janet D. Sparks, * Reza Zolfaghari," Charles E. Sparks," Harold C. Smith," and Edward A. Fisher* \\ *Department of Pathology and Laboratory Medicine, University of Rochester, School of Medicine and Dentistry, Rochester, New York \\ 14642; and ${ }^{\ddagger}$ Department of Physiology and Biochemistry, Medical College of Pennsylvania, Philadelphia, Pennsylvania 19129
}

\begin{abstract}
Studies of streptozotocin-induced diabetes in rats have demonstrated that hepatic apo $B$ and apo $E$ production are reduced. To determine if reductions are related to decreases in hepatic mRNAs, we performed blotting analysis of total liver RNA with rat apo B, apo $E$, and albumin cDNA probes. The expected reduction in albumin mRNA levels to $48 \%$ of control livers occurred in diabetic rat liver, while apo $B$ and apo $E$ mRNA levels were unchanged. The proportion of translational stop codon (BSTOP) mRNA averaged $43 \%$ of total in diabetic rats similar to control levels. Long-term labeling experiments using $\left[{ }^{35}\right.$ S]methionine in primary cultures of rat hepatocytes and specific immunoprecipitations demonstrated production of apo $\mathbf{B}$ and apo $\mathbf{E}$, and albumin by hepatocytes from diabetic rats was reduced to $37 \%, 53 \%$, and $23 \%$ of controls. Pulse-chase studies, together with mRNA analyses, suggest that reduced hepatic secretion of apo $B$ and apo $E$ in diabetics is primarily a result of impaired translation and not intracellular degradation. Ribosome transit studies directly confirmed the prolonged elongation rates for apo $B$ and apo $E$ mRNAs in hepatocytes derived from diabetic rats. This effect was more pronounced on apo $\mathrm{BH}$ (higher molecular weight) than on apo BL (lower molecular weight). Treatment of diabetic rats with insulin for $7 \mathrm{~d}$ led to normalization of hepatic albumin mRNA levels with no substantial change in apo $\mathbf{E}$ mRA levels. In contrast, insulin treatment resulted in significant increases in hepatic apo $B$ mRNA over control levels. Results suggest hepatic albumin and apo $B$ mRNA levels are responsive to insulin in the diabetic state. (J. Clin. Invest. 1992. 89:1418-1430.) Key words: hepatocyte $\bullet$ elongation $\bullet$ mRNA $\bullet$ albumin $\bullet$ insulin
\end{abstract}

\section{Introduction}

Hormonal and metabolic regulation of apo synthesis and lipoprotein assembly is complex (1). Since the liver is a major source of plasma lipoproteins (2), factors affecting hepatic lipoprotein production are important to our understanding of the mechanisms involved in the development of hyperlipoproteinemias. Although there are numerous studies of specific hormone effects on VLDL production by liver, we have focused

Address correspondence and reprint requests to Dr. Janet D. Sparks, Department of Pathology and Laboratory Medicine, University of Rochester, School of Medicine and Dentistry, Box 608, 601 Elmwood Ave., Rochester, NY 14642.

Received for publication 1 August 1990 and in revised form 13 December 1991.

J. Clin. Invest.

(C) The American Society for Clinical Investigation, Inc.

$0021-9738 / 92 / 05 / 1418 / 13 \$ 2.00$

Volume 89, May 1992, 1418-1430 on apo $\mathrm{B}$, not only because apo $\mathrm{B}$ is a requisite component of VLDL and LDL (3), but also because measurement of apo B gives an estimate of number of lipoprotein particles secreted (4). In humans (5) and rats (6-8) there are two forms of apo B, one of higher molecular weight (B-100, apo $\mathrm{BH})^{1}$ and one of lower molecular weight (B-48, apo BL). The two forms of apo $B$ are derived by a novel editing process (9-11) which converts a glutamine codon within the apo B mRNA (BGLN) to a translational stop codon (BSTOP) at position 2153 in humans. Because of apo $\mathrm{B}$ mRNA editing, a shorter translation product is synthesized representing $\sim 48 \%$ of the molecular weight of the complete translation product. B-100 is the predominant form of apo B produced by human liver $(12,13)$ whereas both apo $\mathrm{BH}$ and apo $\mathrm{BL}$ are produced by rat liver $(6-8,14)$. In rats and humans, apo BL (B-48) is the predominant form of apo B produced by the intestine $(5,14)$. Distinctive features of triglyceride-rich lipoproteins containing apo $\mathrm{BL}$ (hepatic and intestinal) are their shorter plasma residence time $(6,14,15)$ and their failure to be converted to LDL (15).

Hormonal and metabolic control of hepatic apo B synthesis and secretion can occur at a number of levels involving changes in apo B mRNA abundance (16-18), apo B mRNA editing (18-20), and through alterations in intracellular apo $B$ degradation (21-24). Hepatic apo B mRNA abundance is increased by $30 \%$ in experimentally hypothyroid rats (16), by $50 \%$ in hypothalamus-lesioned obese rats (17), and by $80 \%$ in $48-\mathrm{h}$ fasted rats (18). Apo B mRNA editing is dramatically increased by thyroid hormone injection $(16,19)$ and by refeeding fasted rats with a high carbohydrate diet (18). In rats fasted for $48 \mathrm{~h}$, hepatic apo $B$ mRNA editing is significantly reduced $(18,20)$. Existing evidence suggests that hepatic apo $B$ secretion can also be affected posttranslationally through degradation of freshly synthesized apo B (21-24). Insulin has been shown to reduce hepatic secretion of apo B $(22,25-28)$ by stimulation of intracellular degradation (22).

In order to understand the complex role of insulin in regulation of hepatic apo B production we have examined the effects of hypoinsulinemic diabetes $(28,29)$. This experimental model is of interest because diabetic rats develop significant hyperlipidemia (30-32) along with increased levels of plasma apo Bcontaining lipoproteins $(29,31)$. The cause of the hyperlipidemia has been attributed to overall increase in lipoprotein formation $(31,32)$ in combination with defective peripheral and hepatic catabolism of triglyceride-rich lipoproteins and LDL

1. Abbreviations used in this paper: $\alpha$-TSF, alpha-toluene sulfonyl fluoride; ALT, alanine amino transferase; apo $B_{H}$, apo $B$ of higher molecular weight in rats (B-100 in humans); apo $B_{L}$, apo B of lower molecular weight in rats (B-48 in humans); BGLN, apo B mRNA containing CAA (glutamine codon-2153 in humans); BSTOP, apo B mRNA containing UAA (translational stop codon-2153 in humans); PCR, polymerase chain reaction; PFK, 6-phosphofructose-2-kinase. 
$(29,31-35)$. VLDL composition is altered in streptozotocin-induced diabetes with a marked reduction in apo $\mathrm{E}$ content $(29$, $31,36)$ which may be a contributory factor to the catabolic defect, as apo $\mathrm{E}$ is an important ligand for hepatic lipoprotein receptors (37). Hepatic secretion of VLDL lipid (36, 38-41) and apo $B$ and $E$ is substantially reduced in both primary cultures of hepatocytes $(28,29)$ and perfused livers derived from diabetic rats $(28,36)$. These findings suggest that the hyperlipidemia of experimental diabetes is primarily a result of the accumulation of intestinally derived chylomicrons and VLDL, and suggest further that the contribution of apo B-containing lipoproteins to the plasma by the liver in the hypoinsulinemic diabetic state is relatively small. Considering that the liver in most circumstances is the major source of plasma VLDL, these findings suggest that endogenous insulin is required for normal hepatic VLDL apo B production. Furthermore, since the majority of plasma apo $E$ is hepatically synthesized (2) and there is a substantial reduction in hepatic apo $E$ secretion in hypoinsulinemic diabetes $(29,36)$, it follows that insulin may also be involved in normal hepatic apo $\mathrm{E}$ production.

The major objective of the present study was to determine if the reduced hepatic secretion of apo $B$ and apo $E$ in experimental diabetes is due to a reduction in apolipoprotein mRNA, to a reduction in apolipoprotein synthesis, or to enhanced intracellular degradation of freshly synthesized apolipoproteins. An additional objective was to evaluate the effect of insulin treatment of the diabetes on hepatic apo $B$ and apo $E$ mRNA levels. Our results indicate that hepatic apo $B$ and apo E mRNA abundance in livers of diabetic rats is not decreased correspondingly with reduced apolipoprotein synthesis. In contrast, both hepatic albumin mRNA and albumin synthesis are correspondingly reduced in diabetic rats. Using primary cultures of hepatocytes derived from diabetic rats, evidence is presented that translational defects at the level of peptide elongation of both apo $B$ and apo $E$ mRNAs underlie the hypoinsulinemic effect. Insulin treatment of diabetic rats resulted in the normalization of hepatic albumin mRNA levels while apo E mRNA levels were unchanged compared with diabetic rats. In contrast, hepatic apo B mRNA increased to 1.9 times that of untreated diabetic rats by insulin treatment. These results indicate that insulin therapy did not act in a generalized fashion to increase all hepatic mRNAs, and suggest that albumin and apo B messages in rat liver are responsive to insulin treatment of the diabetic state.

\section{Methods}

Animals. Male, Sprague Dawley rats (225-250 g) were used for the study. Rats were fasted overnight and made diabetic by injection of streptozotocin $(85 \mathrm{mg} / \mathrm{kg})$ dissolved in $0.01 \mathrm{M}$ citrate buffer, $\mathrm{pH} 4.5$ (29). Control rats were injected with citrate buffer alone. After injection, the animals were refed and allowed access to food and water ad lib. Urine was tested daily for $10 \mathrm{~d}$ for the presence of glucose and ketones, using Ames Keto-Diastix. Animals were not acidotic as evidenced by measured electrolytes $\left(\mathrm{Na}^{+}, \mathrm{K}^{+}, \mathrm{CO}_{2}, \mathrm{Cl}^{-}\right)$. After $10 \mathrm{~d}$, half of the diabetic rats were treated by a single, daily, subcutaneous injection of protamine zinc insulin $(20 \mathrm{U} / \mathrm{kg}$; Eli Lilly and Co., Indianapolis, IN) at 3:00 P.M. After $7 \mathrm{~d}$ of insulin treatment, fed rats were anesthetized with sodium pentobarbital $(25-40 \mathrm{mg} / \mathrm{kg})$ and exsanguinated via the abdominal aorta. Livers were immediately removed, weighed, frozen in liquid nitrogen, and stored at $-80^{\circ} \mathrm{C}$ before RNA isolation. Liver weights $(\mathrm{g})$ of diabetic rats were significantly less than either the control or treated diabetic rats $(P<0.001)$ and averaged $( \pm \mathrm{SD})$ $10.5 \pm 0.97(n=7)$ compared with $13.3 \pm 1.37(n=11)$ in control rats and $13.6 \pm 2.00(n=7)$ in treated diabetic rats. Serum was prepared from blood, and the following serum parameters were measured to characterize animals, including glucose, insulin, apo B, cholesterol, triglyceride, and alanine amino transferase (ALT), as previously described (29). Triiodothyronine $\left(\mathrm{T}_{3}\right)$ was determined by radioimmunoassay (42), and thyroxine $\left(T_{4}\right)$ and free thyroxine $\left(\right.$ free $\left.T_{4}\right)$ were assayed by fluorometric enzyme immunoassay (43).

Isolation of $R N A$. Frozen rat livers were placed into ice-cold buffer containing $5 \mathrm{M}$ guanidinium thiocyanate, $50 \mathrm{mM}$ Tris- $\mathrm{HCl}$ buffer ( $\mathrm{pH}$ 7.5), $25 \mathrm{mM}$ EDTA, and 8\% 2-mercaptoethanol (44), and were homogenized at the highest setting for $30 \mathrm{~s}$ using an instrument (Tekmar Co., Cincinnati, $\mathrm{OH}$ ). RNA was isolated from the homogenate by successive ethanol precipitation in the presence of $6 \mathrm{M}$ guanidine hydrochloride. The final RNA precipitate was dissolved in autoclaved diethyl pyrocarbonate-treated water and stored at $-70^{\circ} \mathrm{C}$ until analysis. The ratio of absorbances at $260 \mathrm{~nm}$ and $280 \mathrm{~nm}$ averaged 1.8 or greater in each group of rats. The yields of total liver RNA averaged (milligram/ gram liver, mean $\pm \mathrm{SD}): 4.3 \pm 1.00(n=11)$ in the control group; $4.3 \pm 0.48(n=7)$ in the diabetic group; and 5.2 $\pm 0.78(n=7)$ in the treated diabetic rat group.

DNA probes. The double stranded cDNA probe for apo B was a 2900-bp cDNA fragment from the $3^{\prime}$ region of rat apo B mRNA (45), and was kindly provided by Dr. A. J. Lusis at the University of California, Los Angeles. Apo E cDNA of $\sim 900$ bp was kindly provided by Dr. L. Chan, Baylor College of Medicine, Houston, TX. The $\beta$-actin probe was a 3400-bp DNA fragment of the mouse $\beta$-actin gene that was provided by Dr. D. Friedman, University of Texas, San Antonio. The rat albumin probe was a full length cDNA probe provided by Dr. T. Sargeant, National Institutes of Health, Bethesda, MD. The ribosomal cDNA, a 1400 -bp fragment that detects the 28 S ribosomal subunit, was supplied by Dr. J. Sylvester, Hahnemann University, Philadelphia, PA. DNA probes were labeled with ${ }^{32} \mathrm{P}$ to a specific activity of greater than $10^{8} \mathrm{cpm} / \mu \mathrm{g} \mathrm{DNA}$, using [ $\left.{ }^{32} \mathrm{P}\right] \mathrm{dCTP}(>3000 \mathrm{Ci} / \mathrm{mmol}$ specific activity) and the random primer method (46).

Blotting analysis of RNA. Total RNAs were size fractionated on formaldehyde denaturing agarose gels by electrophoresis (47), and separated RNAs were transferred to Nytran membranes (Schleicher and Schuell, Inc., Keene, NH), following the manufacturer's protocols (48). For dot blots, total RNA was made $6 \times$ standard saline citrate (SSC) and $7 \%$ formaldehyde, heated at $60^{\circ} \mathrm{C}$ for $15 \mathrm{~min}$, and applied in duplicate at two different concentrations of RNA ( 5 and $10 \mu \mathrm{g}$ ) to Nytran membranes using a Millipore 96-well manifold. After baking the membranes at $80^{\circ} \mathrm{C}$ for $2 \mathrm{~h}$ to fix RNA, membranes were prehybridized, hybridized with labeled probes (49), and then strigently washed to remove nonspecifically bound probe (final conditions were $0.1 \times$ SSC and $57^{\circ} \mathrm{C}$ ). Nytran membranes were autoradiographed using XAR-5 film (Eastman Kodak Co., Rochester, NY) with intensifying screens (Lightning-Plus; Dupont Co., Wilmington, DE) for varying lengths of times at $-70^{\circ} \mathrm{C}$ to assure that signals were within the linear range of the film. Relative signal intensities of autoradiograms were measured by densitometry. The signal obtained from hybridization with the $\beta$-actin DNA probe was not significantly different in control, diabetic, and treated-diabetic rat groups, and averaged (signal intensity \pm SEM): $262 \pm 30$ in the control group; $231 \pm 51$ in the diabetic group; and $202 \pm 56$ in the treated-diabetic group, respectively.

Measurement of edited apo B $m R N A$. Apo B cDNA was synthesized from $2 \mu \mathrm{g}$ of total liver RNA, using $5 \mu \mathrm{M}$ of ND2 deoxy oligonucleotide as reverse transcriptase primer. (ND2, GTTCTTTTTAAGTCCTGTGCATC, $5^{\prime}$ end at nucleotide 6718 of both edited and unedited apo B mRNAs). Reverse transcriptase and reaction conditions were as described by Promega Corp. (Madison, WI). Briefly, 2.5 $\mathrm{U}$ of Taq polymerase (Promega Corp.) and ND2 and ND1 were used in the first nonselective amplification of a 206-mer of apo B, including the editing site. (ND1, ATCTGACTGGGAGAGACAAGTAG, 5' end at nucleotide 6512 of both edited and unedited apo B mRNAs). Competimer-polymerase chain reaction (PCR) was used to quantitate the 
edited and unedited nucleotide in the 206-bp PCR product, essentially as described by Gibbs et al. (50), and as modified by Backus et al. (51).

Preparation of hepatocytes for primary culture. Hepatocytes were prepared for primary culture in serum-free medium (22) and seeded in Waymouth's MB 752/1 medium containing $0.2 \%$, wt/vol, BSA onto 60 -mm dishes coated with rat-tail collagen. The dishes were incubated for $2-4 \mathrm{~h}$ at $37^{\circ} \mathrm{C}$ in an atmosphere of $95 \%$ air $/ 5 \% \mathrm{CO}_{2}$, after which the medium and nonadherent cells were discarded and adherent cells were washed three times with $2.0 \mathrm{ml}$ of HBSS containing $0.2 \%$, wt/vol, BSA. Methionine-free basal medium was prepared from the RPMI 1640 medium-deficient modification (Sigma Chemical Co., St. Louis, MO), to which was added (final concentrations): L-leucine $(0.38 \mathrm{mM})$; L-lysine (1.30 mM); L-glutamine (2.40 mM); choline chloride (1.80 mM); bicarbonate $(24 \mathrm{mM})$; glucose $(28 \mathrm{mM}), 0.2 \%$, wt/vol, BSA; and $0.1 \mathrm{nM}$ insulin (basal conditions). To label cells overnight, media was replaced with methionine-free basal medium $(2 \mathrm{ml} /$ dish $)$ supplemented with 50 $\mu \mathrm{M}$ L-methionine, and $20 \mu \mathrm{Ci} / \mathrm{ml}\left[{ }^{35} \mathrm{~S}\right]-\mathrm{L}$-methionine $(>800 \mathrm{Ci} / \mathrm{mmol}$; Amersham Corp., Arlington Heights, IL), and cells were reincubated for $12-14 \mathrm{~h}$ at $37^{\circ} \mathrm{C}$. For apolipoprotein synthesis studies, liver perfusions of control and diabetic rat livers to prepare hepatocytes were carried out $1 \mathrm{~h}$ apart, and hepatocytes were seeded and cultured in parallel. Performing experiments in pairs assured that rats were under the same light cycle and feeding conditions, and that hepatocytes derived from the rats were cultured identically.

Pulse-chase studies. For pulse-chase studies, hepatocytes were seeded as above, and after $2-4 \mathrm{~h}$ the dishes were washed in $0.2 \%$, wt/ vol, BSA/HBSS and reincubated in Waymouth's MB 752/1 basal medium containing $0.2 \% \mathrm{BSA}$ and $0.1 \mathrm{nM}$ insulin (basal conditions). After overnight incubation (12-14 h), the cells were washed three times and then incubated for 30-40 min in methionine-free medium $(2 \mathrm{ml} /$ dish). To each dish was then added $0.1 \mathrm{ml}$ of $1 \mathrm{mCi} / \mathrm{ml}\left[{ }^{35} \mathrm{~S}\right]$ methionine $(>800 \mathrm{Ci} / \mathrm{mmol})$ also in methionine-free medium. Incubation was continued for exactly $10 \mathrm{~min}$, after which the medium from each dish was quickly withdrawn, monolayers were washed three times, and then reincubated for 10,20 , and $180 \mathrm{~min}$ in $2.0 \mathrm{ml}$ of Waymouth's MB $752 / 1$ containing $0.2 \%$, wt/vol, BSA and $10 \mathrm{mM}$ L-methionine (chase medium) before termination.

Freshly synthesized apolipoproteins were estimated from the average label incorporated into cellular apolipoproteins at 10 and $20 \mathrm{~min}$. Percent recovery of apolipoproteins was calculated as the amount of apolipoprotein label recovered in cells plus media at 180 min divided by the amount of freshly synthesized apolipoproteins, as described previously (22). Apolipoprotein degradation was calculated as the difference in the amount of freshly synthesized apolipoprotein and the amount of labeled apolipoprotein recovered in cells and medium at $180 \mathrm{~min}$ of chase.

Antibodies. Rabbit anti-rat serum albumin (IgG fraction) was obtained from Organon Teknika Corp., West Chester, PA. Rabbit antirat apo B was prepared by immunization of rabbits with SDS-column purified rat apo $B$, as described in detail elsewhere (22). Rat apo E was prepared from VLDL isolated by ultracentrifugation of plasma ( $d$ $<1.006 \mathrm{~g} / \mathrm{ml}$ ) obtained from rats fed a $60 \%$, wt $/ \mathrm{wt}$, sucrose diet (ICN Nutritional Biochemicals, Cleveland, $\mathrm{OH}$ ) for 2 wk. The VLDL was dialyzed against saline and delipidated (52), and apolipoproteins were dissolved in $5 \mathrm{M}$ urea, $2 \mathrm{mM}$ sodium phosphate, $1 \mathrm{mg} / \mathrm{ml}$ dithiothreitol, and $0.01 \%$ sodium azide $\mathrm{pH}$ 7.4. Apo $\mathrm{E}$ was isolated by heparinagarose affinity chromatography (53). To the salt fraction containing rat apo $\mathrm{E}, \mathrm{SDS}$ was added (final concentration, $0.1 \%$, wt/vol), and the sample was dialyzed overnight at room temperature against 6-10 liters of saline containing $0.1 \%$ SDS, wt/vol, using a 15,000-mol wt cut-off dialysis membrane. After dialysis, the sample was lyophilized and dissolved in Tris-buffer containing $2 \% \mathrm{wt} / \mathrm{vol}$, SDS, $5 \%$ vol/vol, 2-mercaptoethanol, and $10 \mathrm{mM}$ dithiothreitol and chromatographed on SDS columns (54). Column fractions containing purified apo $\mathrm{E}$ were determined by molecular weight analysis of the fractions using SDS-PAGE and stained gels (22). After removal of most of the detergent by dialysis against a mixed bed ion exchange resin, apo E-containing fractions were lyophilized and used to immunize rabbits using the same protocol described for apo B immunizations (22). Antisera was tested for antirat apo $\mathrm{E}$ activity by immunodiffusion and western blot analysis (55).

Immunoprecipitation of cellular and media proteins. Hepatocytes were solubilized by scraping cells ( $\sim 1 \mathrm{mg}$ protein per $\mathrm{ml}$ of buffer) into solubilization buffer consisting of $0.05 \mathrm{M}$ Tris buffer, $\mathrm{pH} 7.3,0.15 \mathrm{M}$ $\mathrm{NaCl}, 0.5 \%$ wt/vol, SDS, $1 \%$ vol/vol, Triton X-100, 10 mM EDTA, 10 mM EGTA, $5 \mathrm{mM}$ benzamidine (freshly added), and $2 \mathrm{mM}$ alpha-toluene sulfonyl fluoride ( $\alpha$-TSF) (freshly added). Homogenates were heated $\left(80-90^{\circ} \mathrm{C}\right)$ for $1 \mathrm{~h}$ and spun at room temperature at $2700 \times g$ (relative centrifugal force) for $20 \mathrm{~min}$ to remove debris. An aliquot of the supernatant was then diluted two times its volume with a diluent consisting of $0.05 \mathrm{M}$ Tris buffer, $\mathrm{pH} 7.3,0.15 \mathrm{M} \mathrm{NaCl}, 5 \mathrm{mM}$ EDTA, 5 mM EGTA, $0.5 \% \mathrm{wt} / \mathrm{vol}, \mathrm{BSA}, 2 \mathrm{mM} \alpha$-TSF (freshly added), $2 \mathrm{mM}$ benzamidine (freshly added), $10 \mu \mathrm{g}$ aprotinin/ $\mathrm{ml}, 2 \mu \mathrm{g} / \mathrm{ml}$ leupeptin, and $100 \mu \mathrm{g} / \mathrm{ml}$ soy bean trypsin inhibitor. Media samples were mixed with an equal volume of solubilization buffer and diluent. Specific antiserum was then added to each diluted cell and media sample at a concentration shown to optimally precipitate proteins. Immunoprecipitations were carried out overnight at $4^{\circ} \mathrm{C}$ with mixing, and immune complexes were collected by addition of purified Protein A cells (22). Protein A pellets were washed six times by resuspension in cold $\left(4^{\circ} \mathrm{C}\right)$ $0.05 \mathrm{M}$ Tris buffer, $\mathrm{pH} 7.3$ containing $0.25 \% \mathrm{vol} / \mathrm{vol}$, Triton X-100, $0.1 \% \mathrm{wt} / \mathrm{vol}$, sodium lauryl sarcosine, $0.1 \% \mathrm{wt} / \mathrm{vol}$, BSA, $0.6 \mathrm{mM}$ EDTA, $0.6 \mathrm{mM}$ EGTA, $2 \mathrm{mM}$ benzamidine (freshly added), and $1 \mathrm{mM}$ $\alpha$-TSF (freshly added). Protein A-bound proteins were eluted into Tris buffer containing $2 \% \mathrm{wt} / \mathrm{vol}, \mathrm{SDS}, 5 \% \mathrm{vol} / \mathrm{vol}, 2$-mercaptoethanol, 10 $\mathrm{mM}$ dithiothreitol, $20 \% \mathrm{vol} / \mathrm{vol}$, glycerol, and heated twice to $95^{\circ} \mathrm{C}$ for 5 min (22). Protein A cells were removed by final centrifugation, and an aliquot of the eluate was radioassayed while another aliquot was electrophoresed on $3.5 \%-24 \%$ acrylaide ${ }^{\mathrm{TM}} /$ acrylamide gradient gels cast on GelBond ${ }^{\mathrm{TM}}$ PAGE film (22). Labeled protein bands were visualized by fluorography using preflashed Kodak XAR-5 film at $-80^{\circ} \mathrm{C}$ after the gels were fixed and subsequently enhanced with Autofluor ${ }^{\mathrm{TM}}(22)$. The ratio of apo BH and apo BL label of cells and media was assessed by scanning densitometry of films exposed to enhanced gels.

Ribosome transit time measurements. Ribosome transit times were measured in primary cultures of rat hepatocytes, using the method of Fan and Penman (56) as modified by Palmiter (57). Hepatocytes derived from control and diabetic rats were seeded and cultured in Waymouths MB 752/1 basal medium for 12-14 h. Afterwards, cells were washed in HBSS $/ 0.2 \% \mathrm{wt} / \mathrm{vol}$, BSA three times, and reincubated in RPMI 1640 medium containing $0.2 \% \mathrm{wt} / \mathrm{vol}, \mathrm{BSA}, 50 \mu \mathrm{M}$ L-leucine, and $0.75-2.0 \mu \mathrm{Ci} / \mathrm{ml} \mathrm{L}-\left[{ }^{14} \mathrm{C}\right]$ leucine $(>300 \mathrm{mCi} / \mathrm{mmol}$, Amersham Corp.) for $2 \mathrm{~h}$. Afterwards, cells were brought to room temperature and $100 \mu \mathrm{Ci} /$ dish of $\mathrm{L}-\left[4,5-{ }^{3} \mathrm{H}\right]$ leucine $(120-190 \mathrm{Ci} / \mathrm{mmol}$, Amersham Corp.) was added. Cultures were replaced in the incubator at $37^{\circ} \mathrm{C}$ for various time periods before termination. All subsequent procedures were carried out at $4^{\circ} \mathrm{C}$. At indicated time points, medium was removed from the dish and adjusted to contain $5 \mathrm{mM} \mathrm{MgCl}_{2}, 1 \% \mathrm{vol} / \mathrm{vol}$, Triton X-100, and $1 \% \mathrm{wt} / \mathrm{vol}$, sodium deoxycholate. To the culture dish was added $1-2 \mathrm{ml}$ of cold $\left(4^{\circ} \mathrm{C}\right)$ polysome buffer containing: 250 $\mathrm{mM}$ sucrose; $20 \mathrm{mM}$ Tris- $\mathrm{HCl}, \mathrm{pH} 7.4$ in autoclaved diethylcarbonatetreated water; $5 \mathrm{mM} \mathrm{MgCl}, 25 \mathrm{mM} \mathrm{NaCl}, 40 \mathrm{mg} /$ liter heparin; 100 $\mathrm{mg} /$ liter cycloheximide, $1 \% \mathrm{vol} / \mathrm{vol}$, Triton X-100; $1 \%$, wt/vol, sodium deoxycholate; $5 \mathrm{mM}$ benzamidine (freshly added), $2 \mathrm{mM} \alpha$-TSF (freshly added), $10 \mu \mathrm{g} / \mathrm{ml}$ leupeptin, $100 \mu \mathrm{g} / \mathrm{ml}$ soybean trypsin inhibitor, and $40 \mathrm{U} / \mathrm{ml}$ aprotinin. The cells were scraped from the dish with a teflon scraper and homogenized with five to seven strokes of a glassglass tissue grinder. Each cell homogenate was then recombined with its corresponding labeling media to insure that all of incorporated radioactivity was recovered in the sample. The sample background was determined for each experiment by adding an unlabeled cellular homogenate to fresh experimental media containing both $\left[{ }^{3} \mathrm{H}\right]$ and $\left[{ }^{14} \mathrm{C}\right]$ leucine (58). Samples (homogenates plus medium) were centrifuged at 10,000 $g$ at $4^{\circ} \mathrm{C}$ for $10 \mathrm{~min}$ to prepare postmitochondrial supernatants. Postribosomal supernatants were prepared by subsequent centrifugation at $50,000 \mathrm{rpm}(230,000 \mathrm{~g})$ at $4^{\circ} \mathrm{C}$ in a $70.1 \mathrm{Ti}$ rotor using an ultracentrifuge (L7-65; Beckman Instruments, Inc., Fullerton, CA). To aliquots 
(200-500 $\mu$ l) of the postmitochondrial and postribosomal supernatants were added $250 \mu \mathrm{l}$ of $0.1 \mathrm{M} \mathrm{L}$-leucine in $0.01 \mathrm{~N} \mathrm{HCl}$, and total and completed proteins were precipitated in $7.5 \% \mathrm{wt} / \mathrm{vol}$ TCA. Samples were then placed in a glass bead bath and heated at $95-100^{\circ} \mathrm{C}$ for $1 \mathrm{~h}$, and then centrifuged. Precipitates were washed three to five times with $2 \mathrm{ml}$ of $5 \% \mathrm{wt} / \mathrm{vol}$ TCA containing $10 \mathrm{mM} \mathrm{L}$-leucine. After final centrifugation, supernatants were completely aspirated and pellets were dissolved in $0.3 \mathrm{ml}$ Solvable ${ }^{\mathrm{T}}$ tissue and gel solubilizer (DuPont Co., New England Nuclear Research Products, Boston, MA). For $\beta$-counting, $0.25 \mathrm{ml}$ of the dissolved TCA pellet was mixed with $0.25 \mathrm{ml}$ distilled water and $5.0 \mathrm{ml}$ of Formula 989 liquid scintillation cocktail (New England Nuclear). Immunoprecipitation of completed apo B, apo E, and albumin from postribosomal supernatants were performed essentially as described above, except that postribosomal supernatants were adjusted before overnight incubation with antibody by the following additions (final concentrations): $0.15 \% \mathrm{wt} / \mathrm{vol}, \mathrm{SDS}, 13 \mathrm{mM}$ EGTA; 13 mM EGTA, $0.33 \%$ wt/vol, BSA, $50 \mathrm{mM}$ Tris- $\mathrm{HCl}, 5 \mathrm{mM}$ benzamidine (freshly added), and $2 \mathrm{mM} \alpha$-TSF (freshly added). Immunoprecipitates were washed and eluted as described above. For $\beta$-counting, a 50- $\mu 1$ aliquot of eluted radiolabeled proteins was mixed with $450 \mu$ l distilled water and $5.0 \mathrm{ml}$ Formula 989 liquid scintillation cocktail.

For transit time calculations, the ratio of tritium to carbon-14 was plotted against time after addition of $\mathrm{L}-\left[4,5-{ }^{3} \mathrm{H}\right]$ leucine for the postmitochondrial protein (released plus incomplete polypeptides), postribosomal proteins (released), apo B (released), and apo E (released). Equations of the lines were determined by least-squares fit analysis. From the equations of the lines, $x$ intercepts were calculated and half transit times were determined by subtracting the postmitochondrial $x$ intercept from the $x$ intercepts calculated from the lines of the other proteins. Since the average nascent chain is theoretically half completed after the addition of the first radioactive leucine, the observed half-transit times were doubled to give total transit times $(56,57)$.

Liquid scintillation counting. Liquid scintillation counting was performed using a refrigerated $\beta$-counter (Tri-Carb 4640; Packard Instruments Co., Downers Grove, IL). For measurement of ${ }^{35} \mathrm{~S}$-radioactivity, samples were counted to within $98 \%$ confidence limits. The ratios of ${ }^{3} \mathrm{H}$ and ${ }^{14} \mathrm{C}$ were corrected for quenching in each channel, using the automatic quench correction derived from experimentally derived quench curves and after subtraction of the appropriate background. ${ }^{3} \mathrm{H}-$ radioactivity was counted to within $98 \%$ confidence, while ${ }^{14} \mathrm{C}$-radioactivity was counted to within $95 \%$ confidence limits.

\section{Results}

Characterization of animals. Because of individual animal variability in response to streptozotocin and insulin treatment, rats were fully characterized to make certain that liver donors for mRNA analysis had the associated biochemical features of a severe diabetic state, and that treated diabetic rats showed evidence of reversal of the diabetes. In addition to serum insulin quantitation to document the diabetic state, thyroid status was evaluated. As seen in Table I, diabetic rats were characterized by significant hyperglycemia and hypoinsulinemia. Serum cholesterol and triglycerides were significantly elevated in diabetic rats consistent with increased levels of serum apo B. Serum ALT was elevated in diabetic rats as reported previously (29). Thyroid hormone levels and free $T_{4}$ were significantly reduced in diabetic rats but normalized with insulin therapy.

Effect of diabetes on liver apo $B$ and apo $E$ mRNA. To determine if the reductions previously observed in hepatic apo $B$ and apo E secretion in streptozotocin diabetes correlated with decreased hepatic mRNAs, we compared mRNA levels in livers from control and diabetic rats (Table II). When northern blots of liver RNA were hybridized with the ${ }^{32}$ P-labeled apo B cDNA probe, patterns were essentially identical to previous
Table I. Effect of Streptozotocin-induced Diabetes and Insulin Treatment of Rats on Selected Serum Parameters

\begin{tabular}{lccc}
\hline \multicolumn{1}{c}{ Parameter } & $\begin{array}{c}\text { Control } \\
(n=11)\end{array}$ & $\begin{array}{c}\text { Diabetic } \\
(n=7)\end{array}$ & $\begin{array}{c}\text { Treated } \\
(n=7)\end{array}$ \\
\hline Glucose $(\mathrm{mg} / \mathrm{dl})$ & $135 \pm 56$ & $564 \pm 50^{*}$ & $121 \pm 57$ \\
Insulin $(\mu \mathrm{U} / \mathrm{ml})$ & $85 \pm 7^{\dagger}$ & $9 \pm 4.1^{*}$ & $102 \pm 39$ \\
Apo B $(\mu \mathrm{g} / \mathrm{ml})$ & $83 \pm 55$ & $217 \pm 118^{*}$ & $66 \pm 19$ \\
Cholesterol $(\mathrm{mg} / \mathrm{dl})$ & $44 \pm 5$ & $73 \pm 28^{*}$ & $44 \pm 7$ \\
Triglyceride $(\mathrm{mg} / \mathrm{dl})$ & $61 \pm 29$ & $627 \pm 430^{*}$ & $41 \pm 11$ \\
$\mathrm{ALT}(\mathrm{IU} / \mathrm{liter})$ & $43 \pm 7$ & $163 \pm 115^{*}$ & $51 \pm 20$ \\
$\mathrm{~T}_{3}(\mathrm{ng} / \mathrm{dl})$ & $50 \pm 10.7$ & $20 \pm 10.7^{*}$ & $40 \pm 9.5$ \\
$\mathrm{~T}_{4}(\mu \mathrm{g} / \mathrm{dl})$ & $3.3 \pm 0.37$ & $1.5 \pm 0.26^{*}$ & $3.4 \pm 0.45$ \\
Free $\mathrm{T}_{4}(\mathrm{ng} / \mathrm{dl})$ & $2.8 \pm 0.37$ & $1.7 \pm 0.62^{*}$ & $2.7 \pm 0.57$ \\
\hline
\end{tabular}

Fed rats were anesthetized by sodium pentobarbital injection and exsanguinated via abdominal aorta. Results of serum analyses are expressed as the mean value $\pm \mathrm{SD}$. ${ }^{\dagger} n=6$ rats. ${ }^{*}$ Indicates that results obtained from diabetic rats are significantly different from the control rats using an unpaired $t$ test at a probability level of $P<0.005$.

published results using this probe (45). There was no difference in the integrity of the RNA preparations from control, diabetic, and treated diabetic rat livers as judged by the denaturing gels and northern blot analyses. On ethidium-stained gels for each group the ratio of $28 \mathrm{~S}$ to $18 \mathrm{~S}$ bands was $2: 1$, and with hybridization to apo $\mathrm{E}$, albumin or $\beta$-actin probes, single bands were seen on autoradiographs.

Northern blot analysis of isolated RNA using either labeled apo B cDNA or apo E cDNA probe failed to demonstrate a difference in either hepatic mRNA in diabetic rats compared with control rats. This was confirmed with quantitative dotblot analysis of total liver RNA. Dot-blot results were calculated by densitometry of autoradiographs and were corrected for variable retention of RNA on the nylon membranes using the signal obtained from $\beta$-actin cDNA hybridization. As seen in Table II, the amount of liver apo B and apo E mRNA was similar in control and diabetic rats.

To confirm the significance of the apo B and apo E mRNA results, total liver RNA was also hybridized with a labeled cDNA probe for rat albumin (Table II). Albumin mRNA was chosen for analysis because it has been shown to be reduced in

Table II. Relative mRNA Abundance of Apolipoprotein B, Apolipoprotein E, and Albumin in Control and Streptozotocin Diabetic Rat Livers

\begin{tabular}{lcc}
\hline Specific mRNA & $\begin{array}{c}\text { Control } \\
(n=11)\end{array}$ & $\begin{array}{c}\text { Diabetic } \\
(n=7)\end{array}$ \\
\hline Apolipoprotein B & $0.432 \pm 0.047$ & $0.505 \pm 0.075$ \\
Apolipoprotein E & $0.400 \pm 0.054$ & $0.568 \pm 0.087$ \\
Albumin & $0.877 \pm 0.092$ & $0.422 \pm 0.105^{*}$ \\
\hline
\end{tabular}

Relative mRNA levels were quantitated by dot-blot hybridization of total liver mRNA with labeled cDNA probes. The signals obtained with the test probes were normalized by dividing by the signal obtained with hybridization with a cDNA for $\beta$-actin mRNA. Results in the table are expressed as the mean value \pm SEM. ${ }^{*}$ Indicates that results are significantly different from those obtained with control rats using an unpaired $t$ test at a probability level of $P<0.001$. 
liver relative to total mRNA in experimental diabetes in rats (59). As seen in Table II, relative albumin mRNA levels were significantly reduced to an average of $48 \%$ of control values in untreated diabetic rats.

Effect of diabetes on apo $B \mathrm{mRNA}$ editing. The extent of apo B mRNA editing was determined using competimer PCR of apo $B$ mRNA isolated from control and diabetic rat liver. In control livers, the amount of BSTOP averaged $46 \pm 5 \%$ (SD, $n$ $=6$ ). In three livers from diabetic rats, BSTOP was $31 \%, 47 \%$, and $52 \%$ of the total apo B mRNA, and averaged $43 \% \pm 11 \%$ (SD). These analyses suggest that livers derived from diabetic rats contain control levels of BSTOP and BGLN mRNA.

Effect of diabetes on net apo $B$ synthesis by primary cultures of hepatocytes. In order to determine if the previously observed reduction in apo $B$ secretion by livers derived from diabetic rats was due to an effect on apo B translation, we examined apo B synthesis in corresponding cultures of primary rat hepatocytes. We have previously demonstrated that the reduced hepatic secretion of apo B by liver of diabetic rats is retained by corresponding primary hepatocytes $(28,29)$. Liver perfusions to prepare hepatocytes were carried out $1 \mathrm{~h}$ apart so that hepatocytes derived from control and diabetic livers could be cultured under identical experimental conditions. Hepatocytes were labeled 12-14 h with [ ${ }^{35}$ S]methionine and labeled apo B of cell lysates and media of control, and diabetic hepatocytes was immunoprecipitated and quantitated (Table III). Assuming that cells labeled for 12-14 $\mathrm{h}$ have approached constant specific activity, the apo B label present in cells reflects apo B mass (22). Results from four experiments indicate that the cellular pool of apo $B$ in hepatocytes derived from diabetic rats is, on average, $56 \%$ of that of control levels. This result is consistent with our previous report which indicates that the cellular pool of apo B of hepatocytes derived from diabetic rats was significantly reduced compared with controls using a monoclonal radioimmunoassay which measures an amino terminal-specific epitope present on both apo $\mathrm{BL}_{\mathrm{L}}$ and apo $\mathrm{BH}(29,55)$.

Table III. Incorporation of $L-\left[{ }^{35} S\right]$ Methionine into Cell and Media Apolipoprotein B by Primary Cultures of Hepatocytes Derived from Streptozotocin Diabetic Rats

\begin{tabular}{lccccc}
\hline & Expt. 1 & Expt. 2 & Expt. 3 & Expt. 4 & Mean \pm SD \\
\hline \multicolumn{5}{c}{ Percent of control } \\
Cellular apo B & 48.6 & 67.4 & 40.8 & 67.4 & $56.1 \pm 13.5^{*}$ \\
Media apo B & 10.7 & 20.8 & 38.2 & 47.8 & $29.4 \pm 16.7^{*}$ \\
Total apo B & 21.2 & 35.2 & 39.0 & 51.3 & $36.7 \pm 12.4^{*}$ \\
& & & & \\
\hline
\end{tabular}

Hepatocytes isolated from diabetic and control livers were allowed to adhere for $2-4 \mathrm{~h}$ at $37^{\circ} \mathrm{C}$, after which media and nonadherent cells were removed, and attached cells were washed three times with 2.0 $\mathrm{ml}$ of HBSS containing $0.2 \% \mathrm{wt} / \mathrm{vol}$, BSA. Methionine-free basal medium supplemented with $50 \mu \mathrm{M} L$-methionine and $20 \mu \mathrm{Ci} / \mathrm{ml} \mathrm{L}$ $\left.{ }^{35} \mathrm{~S}\right] \mathrm{methionine}$ was then added to the dishes $(2.0 \mathrm{ml}$ per dish $)$ and hepatocytes were reincubated for $12-14 \mathrm{~h} . \mathrm{L}-\left[{ }^{35} \mathrm{~S}\right]$ methionine label incorporated into apo B was assessed by immunoprecipitation of cell lysates and media as described in Methods. Results are expressed as the label incorporated into apo B by hepatocytes derived from diabetic rats as a percentage of that incorporated into apo $B$ by control hepatocytes in four paired experiments. * Indicates that the means of diabetics are significantly different from the control at a probability level of at least $P<0.005$ using a paired $t$ test.
Labeled apo B of cell and media isolated by immunoprecipitation was separated into apo $\mathrm{BH}$ and apo BL by SDS-PAGE (Fig. 1). In hepatocytes from control rats, cellular apo $B$ radioactivity was present in both apo $\mathrm{BH}$ and apo $\mathrm{BL}$ fractions. The ratio of cellular apo $\mathrm{BL}$ to apo $\mathrm{BH}$ radioactivity averaged $4.2 \pm 1.0$ (SD). Assuming the mass of apo $\mathrm{BL}$ is $48 \%$ of apo $\mathrm{BH}$, the molar ratio of cellular apo $\mathrm{BL}$ to apo $\mathrm{BH}$ in hepatocytes of control rats is about 8-9 to 1 consistent with our previous report (22). In hepatocytes derived from four diabetic rats, the cellular apo B label was mostly apo BL having an estimated labeling ratio of apo $\mathrm{BL}$ to apo $\mathrm{BH}$ of $23.7 \pm 8.4$, giving a calculated molar ratio of about 49 to 1 .

In 12-14-h labeled hepatocytes derived from control rats the ratio of labeled apo $\mathrm{BL}$ to apo $\mathrm{BH}$ which was secreted averaged 2.4 0.72 (SD). On a molar basis this suggests that for every apo $\mathrm{BH}$ particle secreted, three to seven particles of apo $\mathrm{BL}$ are secreted. In contrast, apo B label in 12-14 h labeling media of hepatocytes derived from four diabetic rats demonstrated mainly apo BL having an estimated labeling ratio of apo $\mathrm{BL}$ to apo $\mathrm{BH}$ of $13.0 \pm 4.8$, giving a calculated molar ratio of about 27 to 1 . These results suggest that the net production of apo $\mathrm{BH}$-lipoproteins in 12-14 $\mathrm{h}$ cultures by hepatocytes derived from diabetic rats is significantly depressed.

Effect of diabetes on net apo $B$, apo $E$, and albumin synthesis by primary cultures of hepatocytes. In order to compare the effect of streptozotocin-diabetes on net apo B, apo E, and albumin synthesis, immunoprecipitations were carried out with specific polyclonal antibodies (Fig. 2), using cells and media labeled with $\left[{ }^{35} \mathrm{~S}\right]$ methionine for $12-14 \mathrm{~h}$. Immunoprecipitations for each protein were performed using identical cell lysates and media pools to obtain direct comparisons of label incorporated into apo $\mathrm{B}$, apo $\mathrm{E}$, and albumin in control and diabetic rat hepatocyte preparations. Under these experimental conditions, differences in precursor specific activity in hepatocytes derived from control and diabetic rats are minimal because amino acid pools equilibrate rapidly with media in cultured 


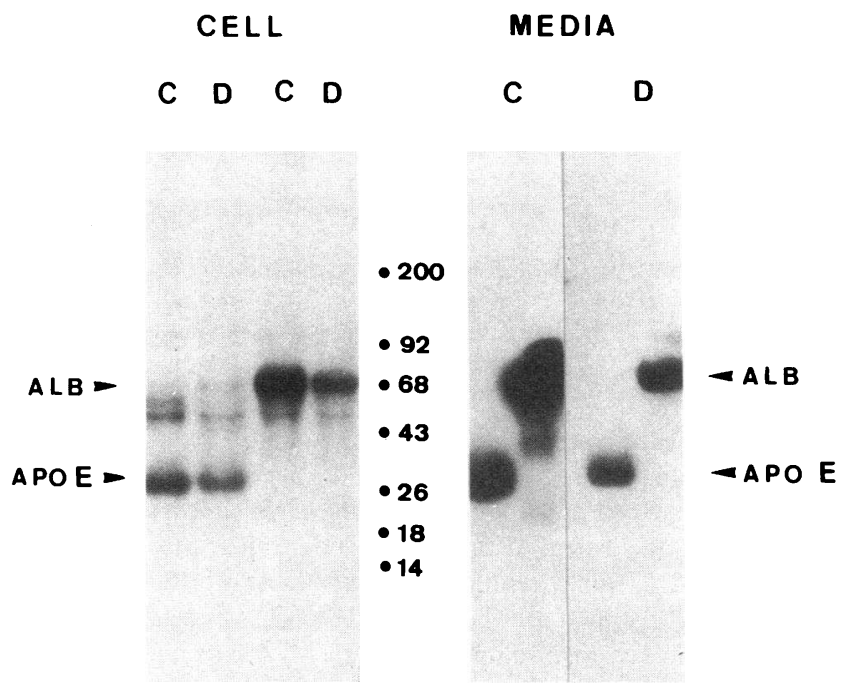

Figure 2. Fluorograph of $\mathrm{L}-\left[{ }^{35} \mathrm{~S}\right]$ methionine-labeled apolipoprotein $\mathrm{E}$ (Apo E) and rat serum albumin (ALB) immunoprecipitated from detergent solubilized cells and media of primary cultures of hepatocytes derived from control $(C)$ and streptozotocin diabetic $(D)$ rats. Primary hepatocyte cultures were labeled $12-14 \mathrm{~h}$ in methionine-free basal medium containing $0.2 \% \mathrm{wt} / \mathrm{vol}$, BSA supplemented with 50 $\mu \mathrm{M}$ L-methionine and $20 \mu \mathrm{Ci} / \mathrm{ml} \mathrm{L}-\left[{ }^{35}\right.$ S $]$ methionine. After incubation, $\left[{ }^{35} \mathrm{~S}\right]$ methionine-labeled apo $\mathrm{E}$ and ALB were isolated by immunoprecipitation from solubilized cells and media using specific rabbit polyclonal antibodies, as described in Methods. After extensive washing of immunoprecipitates, labeled apo E and ALB, eluted from Protein A cells, were separated by SDS-PAGE and labeled bands were visualized by macrofluorography after gel enhancement. In the left panel are cellular immunoprecipitations of apo E ( 2 left lanes) and albumin (2 right lanes). In the right panel are media immunoprecipitations of albumin and apo $\mathrm{E}$ from control hepatocytes ( 2 left lanes) and from hepatocytes derived from diabetic rats (2 right lanes). Migration of molecular weight marker proteins $(\mathrm{kD})$ are indicated in the center panel.

cells (58). No significant difference in precursor specific activity between control hepatocytes and hepatocytes derived from diabetic rats is supported by the finding that the specific activity of cellular and media apo B were similar (Table IV, legend). Assuming that apo $\mathrm{E}$ and albumin are also derived from the same precursor pool as apo B, radioactivity present in cells and media is reflective of the amount of protein present. As seen in Table IV, the net amount of apo B, apo E, and albumin produced in the 12-14-h labeling period was reduced in hepatocytes derived from diabetic rats averaging $44 \%, 53 \%$, and $23 \%$, respectively, of that synthesized by hepatocytes derived from control rats. As apo E mRNA levels are not significantly altered in diabetic rat livers (Table II), the reduced synthesis of apo $E$ is most likely due to either a translational or posttranslational mechanism. Hepatic albumin mRNA is reduced significantly by the diabetic state ( $48 \%$ of the control level), and in hepatocytes derived from diabetic rats, net albumin synthesized is also significantly reduced.

Pulse-chase studies of apo $B$ and apo $E$ in hepatocytes derived from diabetic rats. Pulse-chase studies of apo $B$ and apo $E$ were carried out to obtain an estimate of apolipoprotein translation as in vitro translation is not technically feasible for full length apo $\mathrm{B}$. The 10-min labeling period results in maximum radioactivity incorporated into apo $B$ that continues to elon-

Table IV. Comparison of Incorporation of $L-\left[{ }^{35} S\right]$ Methionine into Cell and Media Apolipoprotein B, E, Albumin, and Total Protein by Primary Cultures of Hepatocytes Derived from Control and Streptozotocin Diabetic Rats

\begin{tabular}{lcc}
\hline & Control & Diabetic \\
\hline \multicolumn{3}{c}{ Apolipoprotein B, dpm $\times 10^{3} / \mathrm{mg}$ cell protein } \\
Cell & $69.7 \pm 15.7$ & $35.0 \pm 4.3^{*}$ \\
Media & $232.1 \pm 36.7$ & $98.9 \pm 28.7^{*}$ \\
Total & $301.9 \pm 30.7$ & $133.9 \pm 32.4^{*}$
\end{tabular}

Apolipoprotein E, dpm $\times 10^{3} / \mathrm{mg}$ cell protein

$\begin{array}{llr}\text { Cell } & 101.8 \pm 23.4 & 49.2 \pm 13.7^{\ddagger} \\ \text { Media } & 514.1 \pm 131.1 & 274.9 \pm 67.0^{\ddagger} \\ \text { Total } & 615.9 \pm 151.9 & 324.3 \pm 80.1^{\ddagger}\end{array}$

Albumin, dpm $\times 10^{3} / \mathrm{mg}$ cell protein

Cell

Media

Total

$$
\begin{gathered}
101.6 \pm 11.0 \\
2,714.7 \pm 633.7 \\
2,816.2 \pm 642.9
\end{gathered}
$$

Total protein, dpm $\times 10^{3} / \mathrm{mg}$ cell protein

Cell plus media

$$
36,991 \pm 3,608
$$

$27,089 \pm 1782^{*}$

Hepatocytes were labeled $12-14 \mathrm{~h}$ at $37^{\circ} \mathrm{C}$ in methionine-free basal medium containing $0.2 \% \mathrm{wt} / \mathrm{vol}$, BSA with added $50 \mu \mathrm{M}$ L-methionine and $20 \mu \mathrm{Ci} / \mathrm{ml} \mathrm{L}\left[{ }^{35} \mathrm{~S}\right]$ methionine. After incubation, media was removed and cells were washed three times in HBSS and solubilized as described in Methods. Incorporation of $\mathrm{L}-\left[{ }^{35} \mathrm{~S}\right]$ methionine into total protein was determined by TCA precipitation of cell and media proteins. Incorporation of $\mathrm{L}-\left[{ }^{35} \mathrm{~S}\right]$ methionine into apo $\mathrm{B}$, apo $\mathrm{E}$, and albumin was assessed by immunoprecipitation from solubilized cell and media pools using specific rabbit polyclonal antibodies. After extensive washing of immunoprecipitates, labeled proteins were eluted from protein A cells and radioassayed. Radioactivity incorporated into specific proteins was corrected for coprecipitated proteins by scanning densitometry of corresponding fluorographs of proteins separated by SDS-PAGE. Immunoprecipitations were performed on 6 pools (2-4 dishes of hepatocytes) derived from 2 control and 2 diabetic rat livers. Results are the average disintegrations per minute incorporated per milligram cell protein \pm SD. ${ }^{*}$ and ${ }^{\ddagger}$ Indicate that the means of diabetics are significantly different from the controls at a probability level of $P<0.001$, and 0.005 , respectively, using an unpaired $t$ test. In the two control and diabetic rat experiments calculated specific activities of apo B (disintegrations per minute/apo B epitope) were: control hepatocytes, 214 and 191; media from control hepatocytes, 229 and 219; hepatocytes derived from diabetic rats, 211 and 215; and media from hepatocytes derived from diabetic rats, 219 and 200 .

gate during the chase after addition of excess "cold" methionine. In both the diabetic and control this plateau is evident, as there is equivalency of the 10 - and 20-min postlabeling cellular apo B label. At 10 min into the chase, there is full-length apo B in control as the chase exceeds the transit time. Fluorographs of apo B immunoprecipitates of hepatocytes derived from diabetic rats suggest that they contain partially translated apo B (Fig. 3) at $10 \mathrm{~min}$ that becomes fully elongated in the chase period as a result of slower, overall translation (Table V). Rate of label incorporated into apo B derived from diabetic rats 


\section{CONTROL CELLS}

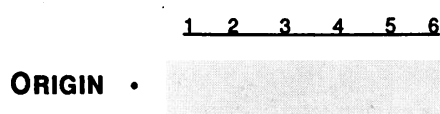

APO BH .

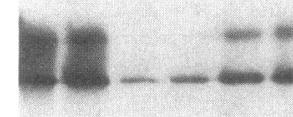

BH •

BL・

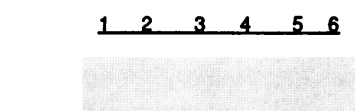

APO BL •

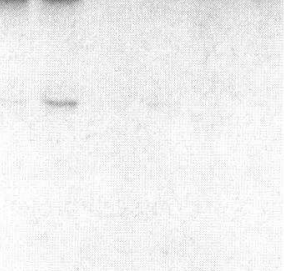

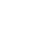

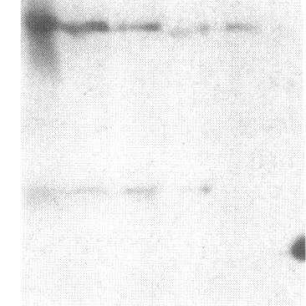

Figure 3. Fluorograph of L- $\left[{ }^{35}\right.$ S $]$ methionine-labeled apolipoprotein B of cells and media of primary cultures of hepatocytes derived from control and streptozotocin diabetic rats in pulse-chase experiments. Primary cultures of rat hepatocytes were incubated 12-14 h in Waymouth's MB 752/1 basal medium containing $0.2 \%$ BSA. The cells were reincubated for 30-40 min in methionine-free medium containing $0.2 \%$ BSA. To each dish was then added $\mathrm{L}-\left[{ }^{35} \mathrm{~S}\right]$ methionine $(100 \mu \mathrm{Ci} /$ dish $)$ and incubation was continued for exactly $10 \mathrm{~min}$. Afterwards, medium from each dish was quickly withdrawn and cells were washed and reincubated in $2.0 \mathrm{ml}$ of Waymouth's MB 752/1 containing $0.2 \% \mathrm{wt} / \mathrm{vol}, \mathrm{BSA}$, and $10 \mathrm{mM}$ L-methionine for a chase period of 10,20 , and $180 \mathrm{~min} .\left[{ }^{35} \mathrm{~S}\right]$ methionine-labeled apo $B$ was isolated by immunoprecipitation from solubilized cells and media using a specific rabbit polyclonal antibody. After extensive washing of immunoprecipitates, labeled apo B, eluted from Protein A cells, was separated into apo $\mathrm{BH}$ and apo $\mathrm{BL}$ by SDS-PAGE, and labeled bands were visualized by macrofluorography after gel enhancement. In three paired experiments, averaging the 10- and 20-min time points, using TCA precipitation and radioassaying supernatants, cellular TCA soluble radioactivity (free amino acid and $t$-RNA label) derived from diabetic rats averaged $1.7 \pm 0.2$ (SD) times the control, indicating that entry of amino acids into cells derived from diabetic rats is not rate limiting. Incorporated $\left[{ }^{35} \mathrm{~S}\right]$ methionine label into apo BTOTAL in hepatocytes derived from control and diabetic rats was (cpm/mg cell protein): $646 \mathrm{cpm} / \mathrm{mg}$ cell protein and $155 \mathrm{cpm} / \mathrm{mg}$ cell protein, respectively. Lanes 1 and 2 are cellular apo $B$ at 10 and 20 min of chase. Lanes 3 and 4 are cellular apo $B$ at 180 min of chase in duplicate dishes, and lanes 5 and 6 are corresponding media apo B label at $180 \mathrm{~min}$ of chase.

averaged $39 \% \pm 16.3 \%$ SD of the label incorporated into apo B in controls in four paired control and diabetic experiments where available precursor label was $1.7 \pm 0.2$ (SD) times higher in diabetic hepatocytes than in control (Fig. 3). The reduced labeling of apo $B$ is an indication of slower translation in hepatocytes derived from diabetic rats. The form of apo B synthesized by hepatocytes derived from diabetic rats was predominantly apo BL (Fig. 3) even during longer times in the chase period to allow for full elongation of apo BH (data not shown). Apo BL label did not disappear from cells even after $180 \mathrm{~min}$ of chase in either control hepatocytes or in hepatocytes derived from diabetic rats consistent with the presence of a cellular pool of apo BL (Fig. 3) as previously described (22).

In similar pulse-chase studies of apo $\mathrm{E}$, using paired cultures of hepatocytes derived from control and diabetic rats, incorporation of label into apo $\mathrm{E}$ by hepatocytes derived from diabetic rats was only $25 \%$ and $35 \%$ of that incorporated by hepatocytes derived from control rats in two paired experi-
Table V. Effect of Diabetes on Ribosome Transit Times of Total Soluble Protein, Apolipoproteins B and E

\begin{tabular}{lccc}
\hline \multicolumn{1}{c}{ Protein fraction } & $\begin{array}{c}\text { Control } \\
n=3\end{array}$ & Diabetic 1 & Diabetic 2 \\
\hline & \multicolumn{3}{c}{ Ribosome transit time, min } \\
Total soluble protein & $3.6 \pm 0.6$ & 5.2 & 8.1 \\
Apolipoprotein B & $9.3 \pm 1.5$ & 37 & 39 \\
Apolipoprotein E & $3.1 \pm 0.3$ & 7.2 & 9.0
\end{tabular}

Primary cultures of hepatocytes derived from control and diabetic rats were incubated in media containing $\mathrm{L}-\left[\mathrm{U}-{ }^{14} \mathrm{C}\right]$ leucine $(0.75-2.0 \mu \mathrm{Ci} /$ dish) for $2 \mathrm{~h}$. Afterwards, $\mathrm{L}-\left[{ }^{3} \mathrm{H}\right]$ leucine $(100 \mu \mathrm{Ci} / \mathrm{dish})$ was added and the cells were reincubated. At various time points thereafter, the cells were homogenized and centrifuged to prepare postmitochondrial and postribosomal supernatants. The ratio of ${ }^{3} \mathrm{H}$ to ${ }^{14} \mathrm{C}$ was determined for total protein and total soluble protein by TCA precipitation. For specific proteins the ratio was determined by immunoprecipitation of the protein from postribosomal supernatants. Results were graphed and ribosome half-transit times were determined from displacement in time between the total protein of the postmitochondrial supernatants and specific proteins. Equations of lines were determined by least-squares fit analysis. Ribosome transit times (min) were calculated by doubling half-transit times.

ments. In contrast to apo $\mathrm{BL}$, apo $\mathrm{E}$ labeled during the pulse period disappeared completely from the cell during the 180 min of chase both in hepatocytes derived from control and diabetic rats (Fig. 4). This result for apo $\mathrm{E}$ is similar to that observed for apo $\mathrm{BH}$ in that pulse-labeled apolipoprotein disappears completely during the chase period (Fig. 3).

Apolipoprotein degradation in hepatocytes derived from diabetic rats. The amount of intracellular apolipoprotein degradation by hepatocytes was calculated as the difference in the amount of fully translated labeled apolipoprotein during the pulse-labeling period, and the amount of labeled apolipoprotein recovered in cells and media at $180 \mathrm{~min}$ of chase. In hepatocytes derived from three diabetic rat livers, the recovery of freshly synthesized apo BL averaged $( \pm \mathrm{SD}): 84 \% \pm 6.4 \%$. Apo BL recovery in hepatocytes derived from diabetic rats did not differ significantly from that previously observed in hepatocytes derived from control rats using similar methods (22). Since most freshly synthesized apo $B L$ is recovered in hepatocytes derived from diabetic rats, the reduction in apo BL secretion by these cells is not primarily due to enhanced intracellular degradation. Hepatocytes derived from diabetic rats synthesized little full-length apo $\mathrm{BH}$ which was inadequate to assess apo BH recovery.

In two paired experiments to measure apo E recovery, an average of $85 \%$ and $93 \%$ of freshly synthesized apo $E$ was recovered in hepatocyte cultures derived from control and diabetic rats, respectively. Since most freshly synthesized apo E was recovered in hepatocytes derived from diabetic rats these results suggest that intracellular apo $\mathrm{E}$ degradation is not a major factor in the reduced hepatic apo E secretion observed in hepatocytes derived from diabetic rats.

Effect of diabetes on average ribosome transit times. Average ribosome transit times were measured in primary cultures of hepatocytes derived from control and diabetic rats, using essentially the method described by Palmiter (57). Results are independent of the rates of attachment of ribosomes to mRNA 


\section{CONTROL CELLS}

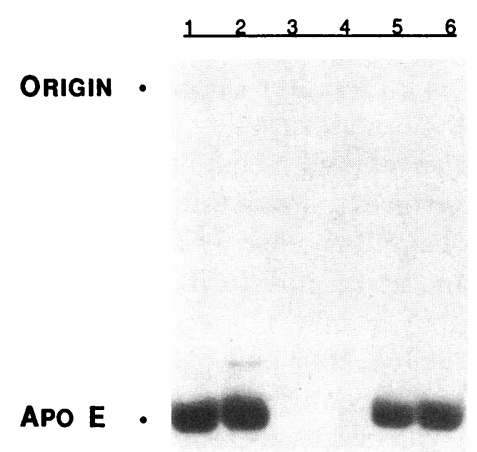

DIABETIC CELLS

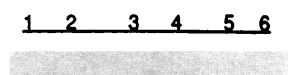

Figure 4. Fluorograph of $\mathrm{L}-\left[{ }^{35} \mathrm{~S}\right]$ methionine-labeled apolipoprotein E of cells and media of primary cultures of hepatocytes derived from control and streptozotocin diabetic rats in pulse-chase experiments. Primary cultures of rat hepatocytes were incubated 12-14 h in Waymouth's MB $752 / 1$ basal medium containing $0.2 \%$ BSA. The cells were reincubated for 30-40 min in methionine-free medium containing $0.2 \%$ BSA. To each dish was then added L- $\left[{ }^{35}\right.$ S $]$ methionine $(100 \mu \mathrm{Ci} / \mathrm{dish})$ and incubation was continued for exactly $10 \mathrm{~min}$. Afterwards, medium from each dish was quickly withdrawn and cells were washed and reincubated in $2.0 \mathrm{ml}$ of Waymouth's MB 752/1 containing $0.2 \% \mathrm{wt} / \mathrm{vol}, \mathrm{BSA}$, and $10 \mathrm{mM} \mathrm{L}$-methionine for a chase period of 10,20 , and $180 \mathrm{~min} .\left[{ }^{35} \mathrm{~S}\right]$ methionine-labeled apo $\mathrm{E}$ was assessed by immunoprecipitation from solubilized cells and media using a specific rabbit polyclonal antibody. After extensive washing of immunoprecipitates, labeled apo E, eluted from Protein A cells, was isolated by SDS-PAGE and visualized by macrofluorography after gel enhancement. Incorporated $\left[{ }^{35} \mathrm{~S}\right]$ methionine label into apo $\mathrm{E}$ in hepatocytes derived from control and diabetic rats was $(\mathrm{cpm} / \mathrm{mg}$ cell protein): $549 \mathrm{cpm} / \mathrm{mg}$ cell protein and $190 \mathrm{cpm} / \mathrm{mg}$ cell protein, respectively. Lanes 1 and 2 are cellular apo $\mathrm{E}$ at 10 and $20 \mathrm{~min}$ of chase. Lanes 3 and 4 are cellular apo $\mathrm{E}$ at $180 \mathrm{~min}$ of chase in duplicate dishes, and lanes 5 and 6 are corresponding media apo $E$ label at 180 min of chase.

and the number of polyribosomes (57). Moreover, using the dual-labeling method (long- and short-term label) and isotope ratios, the method is independent of sample size and recovery. Selective loss of protein due to secretion was eliminated by combining cell homogenates with corresponding media which insures that all incorporated label is present in the sample (58). Ratios of ${ }^{3} \mathrm{H}$ to ${ }^{14} \mathrm{C}$ of postmitochondrial and postribosomal supernatants at each time point were analyzed using TCA precipitation, whereas the ratios for apo $B$ and apo $E$ were determined by specific immunoprecipitations from postribosomal supernatants. The validity of the dual-label method depends upon the ability to separate completed from incomplete polypeptides bound to polyribosomes. In Fig. 5, separation of completed apo $B$ and apo $E$ in the postribosomal supernatant is compared with incomplete apo B polypeptides which were immunoprecipitated from the polysome pellet. Half-ribosome transit times of total soluble protein were determined by the displacement in time of postribosomal and postmitochondrial supernatant proteins. Half-ribosome transit times for apo B and apo $\mathrm{E}$ were calculated from the displacement in time of each protein from the total protein synthesized in postmitochondrial supernatants (Fig. 6). Calculated ribosome transit times in control hepatocytes for total soluble protein, apo B

CONTROL

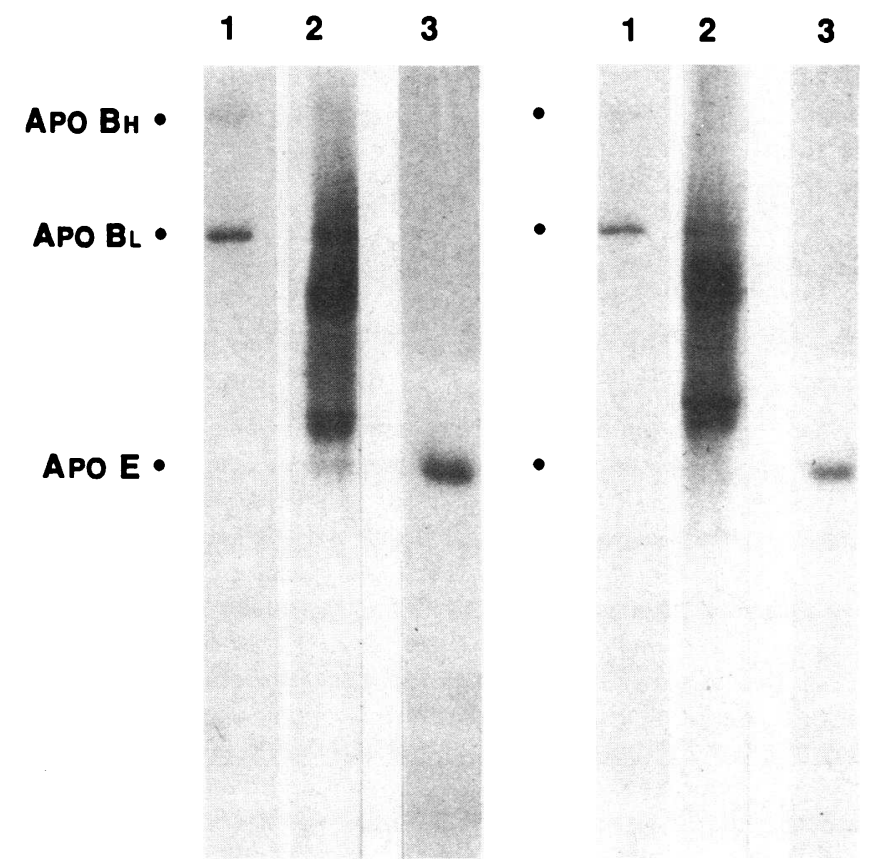

Figure 5. Separation by centrifugation of completed and polysomebound apolipoproteins in hepatocytes derived from control and diabetic rats. Primary cultures of hepatocytes were incubated with $\mathrm{L}-[\mathrm{U}-$ $\left.{ }^{14} \mathrm{C}\right]$ leucine $\left(0.75-2.0 \mu \mathrm{Ci}\right.$ per $60-\mathrm{mm}$ dish) for $2 \mathrm{~h}$. Then, $\mathrm{L}-\left[{ }^{3} \mathrm{H}\right]-$ leucine $(100 \mu \mathrm{Ci} /$ dish) was added and cultures were reincubated and terminated $25 \mathrm{~min}$ later. Cell homogenates were prepared and pooled with corresponding media. Samples were centrifuged at $230,000 \mathrm{~g}$ to separate completed polypeptides (postribosomal supernatants) from polysomes containing incompleted polypeptides (pellet). Labeled apo $B$ and apo $E$ were immunoprecipitated from postribosomal supernatants and apo B was immunoprecipitated from the polysome pellet. After extensive washing of immunoprecipitates, labeled proteins were eluted and separated by SDS-PAGE and gels were fixed, enhanced, and fluorographed. Lanes 1 and 2 are $\mathrm{L}-\left[\mathrm{U}-{ }^{14} \mathrm{C}\right]$ leucine and $\mathrm{L}-\left[{ }^{3} \mathrm{H}\right]-$ leucine-labeled apolipoprotein $\mathrm{B}$ immunoprecipitated from the postribosomal supernatant and polysome pellet, respectively, $25 \mathrm{~min}$ after addition of $\mathrm{L}-\left[{ }^{3} \mathrm{H}\right]$ leucine. Lane 3 is labeled apolipoprotein $\mathrm{E}$ immunoprecipitated from the postribosomal supernatant.

and apo $\mathrm{E}$ averaged 3.6, 9.3, and $3.1 \mathrm{~min}$, respectively. There were prolonged ribosome transit times of total soluble protein, apo $B$ and apo $E$, in hepatocytes derived from diabetic rats which averaged $6.7,38$, and $8.1 \mathrm{~min}$, respectively.

Effect of insulin treatment in vivo on selected RNAs in rat liver. To determine the effect of in vivo insulin treatment of the diabetic state on hepatic apolipoprotein mRNAs, diabetic rats were treated by daily subcutaneous injection of protamine zinc insulin for $7 \mathrm{~d}$ before liver RNA analysis. Blotting analyses of total liver RNA with rat apo $\mathrm{B}$, apo $\mathrm{E}$, and albumin cDNAs were performed on diabetic rats and on rats with documented reversal of the diabetic state (normal glucose, insulin, and ALT). Data are expressed as percent of the control to allow direct comparisons to be made of diabetic and treated diabetic rat liver mRNAs (Table VI). Hybridizations were also performed with a ribosomal 28S RNA cDNA probe in order to determine whether changes in mRNA levels occurred in the context of major alterations in cellular RNA with insulin treatment, since ribosomal RNA is about $85-90 \%$ of the total RNA 

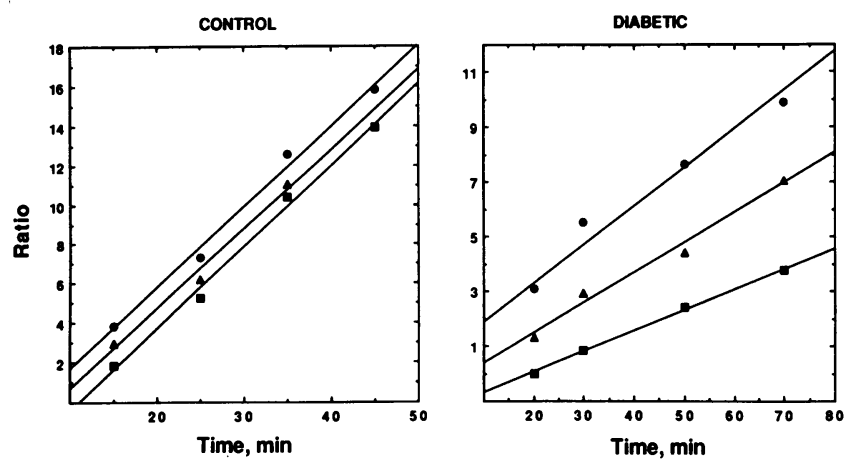

Figure 6. Evaluation of mRNA ribosome transit for total soluble protein, apolipoprotein $\mathrm{B}$ and $\mathrm{E}$ in primary hepatocyte cultures derived from control (left panel) and diabetic rats (right panel). Primary cultures of hepatocytes were incubated with $\mathrm{L}-\left[\mathrm{U}-{ }^{14} \mathrm{C}\right]$ leucine $(0.75-$ $2.0 \mu \mathrm{Ci}$ per $60-\mathrm{mm}$ dish) for $2 \mathrm{~h}$. Then $\mathrm{L}-\left[{ }^{3} \mathrm{H}\right]$ leucine $(100 \mu \mathrm{Ci} / \mathrm{dish})$ was added and cultures were reincubated and terminated at the times indicated. Postmitochondrial supernatants were prepared, followed by centrifugation to remove polysomes and nascent incompleted polypeptides. Ratios of ${ }^{3} \mathrm{H}$ to ${ }^{14} \mathrm{C}$ in postmitochondrial supernatants were determined by TCA precipitation. Ratios of ${ }^{3} \mathrm{H}$ to ${ }^{14} \mathrm{C}$ in specific proteins were determined after immunoprecipitation from postribosomal supernatants, using specific polyclonal antisera as described in Methods. Postmitochondrial supernatants consisting of completed and polysome bound polypeptides are plotted as solid circles. Released apo B and apo E peptides are indicated as solid squares and triangles, respectively.

in the cell. As seen in Table VI, hepatic apo $\mathrm{E}$ and $\beta$-actin mRNA levels and ribosomal 28S RNA of diabetic rats were not significantly different than those in livers of insulin-treated rats. In contrast, insulin treatment of diabetic rats resulted in increases in hepatic apo B and albumin mRNAs which were 1.9 and 2.5 times the value obtained in untreated diabetic rats. The increase in apo B mRNA represents a significant increase over the control value in contrast to albumin.

\section{Discussion}

Previous studies of streptozotocin-induced diabetes in rats have shown that in liver perfusions, hepatic VLDL-lipid (36, $38-40)$ and apo B and apo E secretion $(28,36)$ are reduced, and

Table VI. Effect of Insulin Treatment

of Diabetic Rats on Selected RNAs in Rat Liver

\begin{tabular}{lccc}
\hline \multicolumn{1}{c}{ RNA } & Diabetic rats & Treated diabetic rats & Significance \\
\hline & & Percent of control \\
Apolipoprotein B & $117 \pm 17$ & $223 \pm 16$ & $P<0.001$ \\
Apolipoprotein E & $137 \pm 21$ & $138 \pm 30$ & NS \\
Albumin & $48 \pm 12$ & $122 \pm 18$ & $P<0.004$ \\
$\beta$-Actin & $94 \pm 18$ & $80 \pm 12$ & NS \\
Ribosomal 28 S & $117 \pm 7$ & $103 \pm 8$ & NS \\
& & & \\
\hline
\end{tabular}

Total cellular RNA was extracted from livers of individual animals: 11 control, 7 diabetic, and 7 insulin-treated diabetic rats. Specific RNAs were determined by quantitative dot blotting and results are expressed as a percent of the average of the control group. Values are the means \pm SEM. NS, means of the two groups are not significantly different. this pattern is retained in corresponding cultures of hepatocytes derived from diabetic rats $(28,29,41)$. The reduced secretion of hepatic apo B-containing lipoproteins in long-term hypoinsulinemia suggests that there is an insulin-dependent process which is important in normal hepatic lipoprotein production. To evaluate whether reduced secretion of apo B and apo $\mathrm{E}$ in the diabetic state involves transcriptional control, we measured hepatic mRNA of apo $B$ and apo E. To confirm the significance of the apo B and apo E mRNA data we also measured hepatic albumin mRNA, as others have shown that albumin mRNA abundance relative to total poly (A+)-RNA is reduced to between $63 \%$ and $28 \%$ of controls after alloxan injection to induce diabetes (59). Our results also show, using a different assay technique, a significant reduction of hepatic albumin mRNA (48\% of control levels) in streptozotocin diabetic rat livers. This finding demonstrates that the method for mRNA quantitation used in our study is sensitive enough to detect similar reductions in hepatic apo $B$ or apo $E$ mRNA had changes taken place in the diabetic state. The current studies demonstrate that apo B and apo E mRNA levels are not significantly affected by chronic hypoinsulinemia suggesting the involvement of a translational or posttranslational mechanism in their reduced secretion.

Decreases and increases in the concentrations of specific hepatic mRNAs and corresponding proteins in hypoinsulinemic diabetes have recently been reviewed (60). In livers of diabetic rats, decreased mRNA levels correlate with decreased synthesis of albumin, glucokinase, tyrosine amino transferase, fatty acid synthetase, and pyruvate kinase, and increased mRNA levels correlate with increased synthesis of phosphoenolpyruvate carboxykinase (60) and phenylalanine hydroxylase (61). Results of the current study of hepatic apo B and apo $E$ indicate that their corresponding $\mathrm{mRNAs}$ are not changed substantially by hypoinsulinemic diabetes, but their synthesis and secretion are significantly reduced. Minimal changes in hepatic mRNA levels of hepatic 6-phosphofructose-2-kinase (PFK) with reduced PFK synthesis have been reported in insulin-deficient diabetes (62) which is similar to the current results obtained for apo B and apo $\mathrm{E}$. The mechanism involved in the reduction of hepatic PFK, apo $B$, and apo $E$ could be decreased translational efficiency of these specific mRNAs, or to increased protein turnover, or both.

Impaired hepatic protein synthesis in experimental diabetes due to insulin deficiency could occur through reduction in tissue RNA leading to an absolute decrease in translation. In the current studies, hepatic RNA content (milligram RNA/ gram liver) and ribosomal $28 \mathrm{~S}$ subunit in control and diabetic livers were similar making major losses in the capacity of diabetic rat livers to synthesize proteins, an unlikely mechanism for the observed reduction in protein synthesis. A number of investigators have observed a decrease in protein synthesis in vitro, using poly (A+) RNA derived from livers of hypoinsulinemic diabetic rats (61), and the reason for this may relate to reduced initiation or involve a defect in peptide elongation. Decreases in polysomes in livers of diabetic rats have been reported (63) that would be consistent with defective peptide initiation and elongation. There is general agreement that the synthesis of secretory proteins is reduced to a much greater extent in hypoinsulinemic diabetes than the synthesis of intracellular proteins (64). Because secretory proteins are primarily synthesized in the rough endoplasmic reticulum, disruption of mem- 
brane-bound polysomes in diabetic states $(38,63)$ could explain the more pronounced effect of insulin-deficiency on synthesis of secretory proteins, compared with the synthesis of cellular proteins which are translated primarily on free polyribosomes. It would be predicted that the reduction in secretory protein synthesis and secretion would be a general effect observed for all secretory proteins. There does, however, appear to be disproportionate change in the synthesis of certain secretory proteins, particularly glycoproteins (65) including alpha1-acid-glycoprotein of Darcy (66).

To determine whether a translational mechanism is involved in the reduced secretion of hepatic apo $B$ and apo $E$ in hypoinsulinemic diabetes, we compared their synthesis using long-term labeling (12-14 h) in primary cultures of hepatocytes derived from control and diabetic rats (Table IV). The specific activity of cellular and media apo B in hepatocytes derived from control, and diabetic rats were similar supporting the idea that the extent of label incorporation reflects amount of protein present. In these comparative studies the production of apo B, apo $\mathrm{E}$, and albumin is reduced by the diabetic state to $44 \%$, $53 \%$, and $23 \%$, respectively, of control levels. In addition, the hepatic pool of apo BL in hepatocytes derived from diabetic rats is significantly reduced, compared with control hepatocytes.

Long-term labeling studies reflect "net" apolipoprotein production, and, therefore, do not measure synthesis or extracellular catabolism directly. Previous studies in control cultures which measured degradation of radioiodinated lipoprotein added to media indicate that $15 \%$ of added lipoprotein is degraded in 18-h cultures (25). In our studies using nonfasted, radioiodinated triglyceride-rich lipoprotein $(d<1.006 \mathrm{~g} / \mathrm{ml}$, VLDL including remnants) and low density lipoprotein (1.019 $<d<1.063 \mathrm{~g} / \mathrm{ml}$ including IDL), $27 \%$ of TRL and LDL apo B were degraded over $16 \mathrm{~h}$ in culture (29). In hepatocytes derived from diabetic rats, the degradation of apo $B$ of TRL and LDL is significantly reduced to $\sim 10 \%(29)$. As hepatocytes derived from diabetic rats degrade less lipoprotein added to media than control cells, it is unlikely that the observed reduction in lipoprotein production by hepatocytes derived from diabetic rats is the result of increased postsecretory catabolism by these cells.

To study impairment in translation in diabetes, we examined apo B and apo E synthesis and secretion using a pulsechase protocol in primary cultures of hepatocytes. Using a short period of incubation with $\left[{ }^{35} \mathrm{~S}\right]$ methionine label $(10 \mathrm{~min})$, and by measuring incorporation into apolipoproteins early in the chase period before secretion takes place, an estimate of apolipoprotein synthesis can be made directly (22). The impairment in apo B and apo E synthesis by hepatocytes derived from diabetic rats was apparent, as label incorporated into apo $B$ and apo $E$ was reduced to $39 \%$ for apo B and $30 \%$ for apo E compared with control hepatocytes. Both long-term and pulsechase studies suggest impairment of hepatic apo B and apo E translation in streptozotocin-diabetic rats. To rule out the possibility that reduced hepatic production of apo $B$ and apo $E$ was due to posttranslational, intracellular degradation before secretion, we measured the recovery of pulse-labeled apolipoproteins after $180 \mathrm{~min}$ of chase. Our results demonstrate that greater than $84 \%$ and $93 \%$ of freshly synthesized, full length apo $\mathrm{BL}$ and apo $\mathrm{E}$, respectively, were recovered in media, plus hepatocytes derived from diabetic rats. These results suggest that posttranslational, intracellular degradation of apo $\mathrm{BL}$ and apo $\mathrm{E}$ is not primarily responsible for the observed reduction in apolipoprotein secretion in hepatocytes derived from diabetic rats.

Very little apo $\mathrm{BH}$ was synthesized in pulse-chase studies by hepatocytes derived from diabetic rats compared with controls limiting our ability to assess translational parameters and recovery of apo BH. Consistent with its reduced synthesis, labeled apo $\mathrm{BH}$ is almost completely absent from steady state labeled hepatocytes derived from diabetic rats compared with its presence in control hepatocytes (22). One explanation for this finding could be that most of the apo B mRNA present in livers of diabetic rats is BSTOP and contains the translational stop codon. This possibility is unlikely since direct analysis of BGLN and BSTOP indicates that the proportion of the message coding for apo $\mathrm{BH}$ is normal in diabetic liver. However, the percentage of apo BGLN mRNA is of the total cellular apo B mRNA and it is possible that a portion of the BGLN message is sequestered in an inactive form. Another possibility is that differences in translational efficiency may be involved considering the twofold larger size of the translation sequence of apo BH compared to apo $\mathrm{BL}$.

Ribosome transit studies were undertaken to explore the possibility that the defect in translation we observed for apo B and apo $\mathrm{E}$ in the diabetic state was related to a prolongation in peptide elongation. Using the isotope ratio method outlined by Palmiter (57) with modifications for use in cultured cells (58), the ribosome transit time is independent of the rates of attachment of ribosomes to mRNA and the number of polyribosomes. The ribosome transit time for total soluble protein for control hepatocytes was similar to that reported for suspensions of control hepatocytes (59), and apo B transit time is similar to reported values (67). A prolonged transit time for total soluble protein was not observed in diabetic rats by others (59), in contrast to presented results. The reasons for this difference are not known, although experimental conditions differ. We used streptozotocin, compared with alloxan, to induce hypoinsulinemic diabetes, and primary cultures of hepatocytes were used instead of acute suspension cultures. Moreover, we used a double label method employing ratios of ${ }^{3} \mathrm{H}$ and ${ }^{14} \mathrm{C}$ label in both long and short times, compared with the use of a single label. The total protein transit time increased from 3.6 to 6.7 min (difference of $3.1 \mathrm{~min}$ ), compared with apo $\mathrm{E}$ which increased from 3.1 to $8.1 \mathrm{~min}$ (difference of $5 \mathrm{~min}$ ) and apo B which increased from 9.3 to $38 \mathrm{~min}$ (difference of $29 \mathrm{~min}$ ). Apo $B$ was increased more than four times the control which is even more dramatic when expressed as total transit time. These results suggest there are factors specific for apo B, one of which may be the unusual length of the mRNA, which are responsible for the dramatically prolonged elongation. Consistent with this finding is the almost complete inability to translate apo $\mathrm{BH}$ in spite of available mRNA in the diabetic rat.

Regulatory events that could affect polypeptide chain elongation include changes in activities of elongation factors, variations in the secondary structure of mRNA, as well as changes in the physical properties of the membranes to which ribosomes become attached. There is also the possibility that peptide elongation could be affected by the conformation of the growing peptide chain which could be altered by cotranslational modifcations such as fatty acylation and phosphorylation. Considering the unique role of apo B as a lipid binding and transport protein, cotranslational modification of apo B might play an 
important role in controlling translational efficiency, as lipid assembly may be obligatory for efficient apo B translation. There are known changes in diabetes, including decreased lipid synthesis $(30,41)$ and increased apo B phosphorylation (68), which could play a part in the control of apo B translational efficiency.

Selective reduction in hepatic secretory proteins in hypoinsulinemic diabetes including apo B and apo E could relate to involvement of mRNA associated proteins ( $m R N P s$ ) in modulating specific changes in mRNA translational efficiency. Proteins, bound by mRNAs, are believed to maintain specific messages in either a translatable or nontranslatable state, and may be important in the association of $m R N A s$ with the cytoskeletal elements of the cell (69). It is of interest that recent studies employing apo B mRNA sequences and rat liver $\mathrm{S} 100$ cytosolic extracts indicate that a portion of hepatic apo $B$ mRNA is present in liver as a macromolecular, mRNP complex (70). This complex is believed to be important for the editing of the specific glutamine codon introducing a translational stop codon. How much apo B mRNA in liver is associated with the complex (nuclear or cytoplasmic) and whether the complex allows for simultaneous translation of the apo B mRNA is unknown.

The mechanisms of development of hyperlipoproteinemia in experimental diabetes and their relationships to mechanisms involved in hyperlipoproteinemia associated with human diabetes mellitus is controversial $(30,71)$. Studies in experimental models of diabetes demonstrate that insulin deficiency lowers hepatic apo B $(28,29)$ and VLDL-triglyceride secretion $(40$, 41 ), and with long-term insulin treatment in vivo, hepatic apo B production normalizes (28). Our studies suggest a positive correlation between plasma insulin levels and hepatic triglyceride-rich lipoprotein production, and such a correlation is supported by studies which raise ambient plasma levels by insulin injection (72), continuous insulin infusion (73), and sucrosefeeding (74). Current studies support the concept that there is an insulin-dependent process which is important in hepatic apo $B$ and apo $E$ production. The positive relationship between ambient insulin levels and hepatic lipoprotein-apo B production contrasts with results of short-term studies in primary rat hepatocyte cultures (25-28) and in rat liver perfusion (28) which demonstrate that high levels of insulin inhibit hepatic apo $B$ and VLDL secretion. The insulin inhibition of hepatic VLDL formation occurs at concentrations of insulin consistent with postprandial portal levels, and is reversible after withdrawal of insulin (25). We have shown previously (26) that the insulin effect on apo B is not synchronous with insulin-stimulated lipid synthesis. At low concentrations $(0.1 \mathrm{nM})$, insulin stimulates lipid synthesis from acetate, and at higher concentrations (> $10 \mathrm{nM}$ ), while continuing to stimulate lipid synthesis, insulin inhibits VLDL particle secretion of both apo B and triglyceride components (26). Recent studies suggest that triglyceride accumulates in insulin-treated hepatocytes as cytoplasmic droplets (75) and not as preassembled lipoproteins, consistent with the lack of accumulation of cellular apo B in insulin-treated hepatocytes (22). We have recently shown that the primary mechanism involved in the suppressive effect of insulin on apo B secretion by liver is an effect on intracellular degradation of freshly synthesized apo B (22), a component of VLDL that is obligatory for lipoprotein formation. The insulin effect favors apo BH (B-100) degradation, compared with apo
BL (B-48) (22). We hypothesize that the insulin degradation pathway relates to cyclical suppression of hepatic VLDL production to minimize competition of catabolic pathways in the postprandial state. We found little evidence for apo B (apo BL) degradation in hepatocytes derived from diabetic rats consistent with their hypoinsulinemic state. From current and previous studies it is clear that there are both long-term and shortterm insulin-dependent regulatory mechanisms involved in the control of hepatic VLDL apo B production $(28,76)$.

Experimental diabetes in rats also affects VLDL particle composition $(29-31,36)$ with a marked reduction in apo $\mathrm{E}$. Considering the role of apo $\mathrm{E}$ in removal of both hepatic and intestinal triglyceride-rich lipoproteins (37), it is important to explore the potential for additional catabolic defects in diabetic states created by altered particle composition resultant from changes in hepatic apo $\mathrm{E}$ production. Initial experiments involving apo $E$ in the current study suggest that there are decreases in hepatic apo E secretion which could have such an effect. We present evidence that reduced apo $\mathrm{E}$ production is primarily a result of slowed translation similar to apo B, and not the result of decreased mRNA levels or increased intracellular apo E degradation. Regulation of hepatic apo E mRNA levels is complex. In regenerating rat liver, apo E mRNA levels are decreased due to both transcriptional and posttranscriptional mechanisms (77). In development, hepatic apo $\mathrm{E}$ mRNA is also low and progressively increases to adult levels shortly after birth (78). In adult rats, dexamethasone treatment does little to affect hepatic apo E mRNA (78), and in primary cultures of rat hepatocytes apo E mRNA is relatively stable to the presence of dexamethasone, insulin, and insulin, plus dexamethasone in the media (78). Secretion of apo $\mathrm{E}$ is greatly enhanced when hepatocytes are cultured in media containing insulin plus dexamethasone (79) consistent with translational control.

An important preliminary observation is the responsiveness of apo B and albumin mRNA to insulin treatment in the diabetic state. Hepatic apo E mRNA did not increase using this same treatment protocol. Although apo A-I metabolism was not comprehensively studied, preliminary blotting analysis for apo A-I mRNA indicates that insulin treatment significantly lowered apo A-I mRNA in treated diabetic rats, compared with diabetic rats [ $68 \pm 9$ versus $153 \pm 31$, as a percent of control and calculated as described in Table VI, $P<0.007$ ]. These results suggest that insulin treatment of the diabetic state has different effects on different apolipoprotein mRNAs. Interestingly, apo $B$ production in liver perfusions of treated diabetic rats was normalized (28), and not increased after insulin treatment in vivo suggesting the involvement of additional factors other than mRNA abundance in regulation of apo $B$ production by liver in treated diabetic rats.

The investigation of factors such as free fatty acid supply or mode of insulin administration, which may be involved in the regulation of hepatic lipoprotein production in treated diabetic rats, must be fully evaluated before attempting to relate the current results of insulin treatment of diabetic rats to humans. Although hepatic apo B mRNA increased with insulin administration to diabetic rats, treatment by insulin injection is nonphysiologic and likely results in systemic hyperinsulinemia (72), as opposed to cyclic portal release of insulin. In addition, in treated diabetics there are higher insulin levels in the peripheral circulation, unlike normal postprandial insulin that is pre- 
dominantly portal. Increased hepatic apo B mRNA also occurs in hypothalamus-lesioned obese rats that are known to be hyperinsulinemic (17). The current studies demonstrate the insulin responsiveness of hepatic apo B mRNA levels at least in the environment of diabetes.

Our results support differences in long-term and short-term effects of insulin on VLDL metabolism, and suggest a necessary role for insulin in the regulation of hepatic triglyceriderich lipoprotein production.

\section{Acknowledgments}

We gratefully acknowledge the excellent technical assistance of Mary Bolognino, Cecelia Pascuzzi, and Joanne Cianci in performance of these studies, and Dr. G. T. Rizzo for thyroid hormone assays. We would like to thank the following investigators for probes: Dr. A. J. Lusis for the rat apo B cDNA, Dr. L. Chan for the apo E cDNA, Dr. D. Friedman for the mouse $\beta$-actin DNA probe, Dr. T. Sargeant for the rat albumin cDNA, and Dr. J. Sylvester for the ribosomal cDNA.

This work was supported by HL-29837 (C. E. Sparks) from the National Heart, Lung, and Blood Institute, the American Diabetes Association (J. D. Sparks), W. W. Smith Charitable Trust (E. A. Fisher), and the Council for Tobacco Research (E. A. Fisher).

\section{References}

1. Gibbons, G. F. 1990. Assembly and secretion of hepatic very-low-density lipoprotein. Biochem. J. 268:1-13.

2. Wu, A-L., and H. G. Windmueller. 1979. Relative contributions by liver and intestine to individual plasma apolipoproteins in the rat. J. Biol. Chem. 254:7316-7322.

3. Gotto, A. M., R. I. Levy, K. John, and D. S. Fredrickson. 1971. On the protein defect in abetalipoproteinemia. $N$. Engl. J. Med. 284:813-818.

4. Elovson, J., J. E. Chatterton, G. T. Bell, V. N. Schumaker, M. A. Reuben, D. L. Puppione, J. R. Reeve, Jr., and N. L. Young. 1988. Plasma very low density lipoproteins contain a single molecule of apolipoprotein B. J. Lipid Res. 29:1461-1473.

5. Kane, J. P. 1983. Apolipoprotein B: structural and metabolic heterogeneity. Annu. Rev. Physiol. 45:637-650.

6. Sparks, C. E., and J. B. Marsh. 1981. Metabolic heterogeneity of apolipoprotein B in the rat. J. Lipid Res. 22:519-527.

7. Krishnaiah, K. V., L. F. Walker, J. Borensztajn, G. Schonfeld, and G. S. Getz. 1980. Apolipoprotein B variant derived from rat intestine. Proc. Natl. Acad. Sci. USA. 77:3806-3810.

8. Elovson, J., Y. O. Huang, N. Baker, and R. Kannan. 1981. Apolipoprotein B is structurally and metabolically heterogeneous in the rat. Proc. Natl. Acad. Sci. USA. 78:157-161.

9. Chen, S-H., G. Habib, C-Y. Yang, Z-W. Gu, B. R. Lee, S-A. Weng, S. R. Silberman, S-J. Cai, J. P. Deslypere, M. Rosseneu, et al. 1987. Apolipoprotein B-48 is the product of a messenger RNA with an organ-specific in-frame stop codon. Science (Wash., DC). 238:363-366.

10. Powell, L. M., S. C. Wallis, R. J. Pease, Y. H. Edwards, T. J. Knott, and J. Scott. 1987. A novel form of tissue-specific RNA processing produces apolipoprotein-B48 in intestine. Cell. 50:831-840.

11. Hospattankar, A. V., K. Higuchi, S. W. Law, N. Meglin, and H. B. Brewer, Jr. 1987. Identification of a novel in-frame translational stop codon in human intestine apo B mRNA. Biochem. Biophys. Res. Commun. 148:279-285.

12. Rash, J. M., G. H. Rothblat, and C. E. Sparks. 1981. Lipoprotein apolipoprotein synthesis by human hepatoma cells. Biochim. Biophys. Acta. 666:294298.

13. Edge, S. B., J. M. Hoeg, P. D. Schneider, and H. B. Brewer, Jr. 1985. Apolipoprotein B synthesis in humans: liver synthesizes only apolipoprotein B-100. Metab. Clin. Exp. 34:726-730.

14. Sparks, C. E., O. Hnatiuk, and J. B. Marsh. 1981. Hepatic and intestinal contribution of two forms of apolipoprotein B to plasma lipoprotein fractions in the rat. Can. J. Biochem. 59:693-699.

15. Sparks, C. E., D. J. Rader, and J. B. Marsh. 1983. Metabolism of two forms of apolipoprotein B of VLDL by rat liver. J. Lipid Res. 24:156-166.

16. Davidson, N. O., R. C. Carlos, M. J. Drewek, and T. G. Parmer. 1988. Apolipoprotein gene expression in the rat is regulated in a tissue-specific manner by thyroid hormone. J. Lipid Res. 29:1511-1522.

17. Inui, Y., S. Kawata, Y. Matsuzawa, K. Tokunaga, S. Fujioka, S. Tamura, T. Kobatake, Y. Keno, and S. Tarui. 1989. Increased level of apolipoprotein B
mRNA in the liver of ventromedial hypothalamus lesioned obese rats. Biochem. Biophys. Res. Commun. 163:1107-1112.

18. Baum, C. L., B-B. Teng, and N. O. Davidson. 1990. Apolipoprotein B messenger RNA editing in the rat liver. Modulation by fasting and refeeding a high carbohydrate diet. J. Biol. Chem. 265:19263-19270.

19. Davidson, N. O., L. M. Powell, S. C. Wallis, and J. Scott. 1988. Thyroid hormone modulates the introduction of a stop codon in the rat liver apolipoprotein B messenger RNA. J. Biol. Chem. 263:13482-13485.

20. Leighton, J. K., J. Joyner, J. Zamarripa, M. Deines, and R. A. Davis. 1990. Fasting decreases apolipoprotein B mRNA editing and the secretion of small molecular weight apo B by rat hepatocytes: evidence that the total amount of apo B secreted is regulated post-transcriptionally. J. Lipid Res. 31:1663-1668.

21. Borchardt, R. A., and R. A. Davis. 1987. Intrahepatic assembly of very low density lipoproteins. Rate of transport out of the endoplasmic reticulum determines rate of secretion. J. Biol. Chem. 262:16394-16402.

22. Sparks, J. D., and C. E. Sparks. 1990. Insulin modulation of hepatic synthesis and secretion of apolipoprotein B by rat hepatocytes. J. Biol. Chem. 265:8854-8862.

23. Sato, R., T. Imanaka, A. Takatsuki, and T. Takano. 1990. Degradation of newly synthesized apolipoprotein B-100 in a pre-Golgi compartment. J. Biol. Chem. 265:11880-11884.

24. Dixon, J. L., S. Furukawa, and H. N. Ginsberg. 1991. Oleate stimulates secretion of apolipoprotein B-containing lipoproteins from Hep G2 cells by inhibiting early intracellular degradation of apolipoprotein B. J. Biol. Chem. 266:5080-5086.

25. Patsch, W., S. Franz, and G. Schonfeld. 1983. Role of insulin in lipoprotein secretion by cultured rat hepatocytes. J. Clin. Invest. 71:1161-1174.

26. Sparks, C. E., J. D. Sparks, M. Bolognino, A. Salhanick, P. S. Strumph and J. M. Amatruda. 1986. Insulin effects on apolipoprotein B lipoprotein synthesis and secretion by primary cultures of rat hepatocytes. Metab. Clin. Exp. 35:1128-1136.

27. Patsch, W., A. M. Gotto, Jr., and J. R. Patsch. 1986. Effects of insulin on lipoprotein secretion in rat hepatocyte cultures. The role of the insulin receptor. $J$. Biol. Chem. 261:9603-9606.

28. Sparks, J. D., C. E. Sparks, and L. L. Miller. 1989. Insulin effects on apolipoprotein B production by normal, diabetic and treated-diabetic rat liver and cultured rat hepatocytes. Biochem. J. 261:83-88.

29. Sparks, J. D., C. E. Sparks, M. Bolognino, A. M. Roncone, T. K. Jackson, and J. M. Amatruda. 1988. Effects of nonketotic streptozotocin diabetes on apolipoprotein B synthesis and secretion by primary cultures of rat hepatocytes. $J$. Clin. Invest. 82:37-43.

30. Gibbons, G. F. 1986. Hyperlipidaemia of diabetes. Clin. Sci. (Lond.) 71:477-486.

31. O'Looney, P., D. Irwin, P. Briscoe, and G. V. Vahouny. 1985. Lipoprotein composition as a component in the lipoprotein clearance defect in experimental diabetes. J. Biol. Chem. 260:428-432.

32. Levy, E., E. Shafrir, E. Ziv, and H. Bar-On. 1985. Composition, removal and metabolic fate of chylomicrons derived from diabetic rats. Biochim. Biophys. Acta. 834:376-385.

33. Brunzell, J. D., D. Porte, Jr., and E. L. Bierman. 1979. Abnormal lipoprotein lipase-mediated plasma triglyceride removal in untreated diabetes mellitus associated with hypertriglyceridemia. Metab. Clin. Exp. 28:901-907.

34. Goldberg, A. P., A. Chait, and J. D. Brunzell. 1980. Postprandial adipose tissue lipoprotein lipase activity in primary hypertriglyceridemia. Metab. Clin. Exp. 29:223-229.

35. Chait, A., E. L. Bierman, and J. J. Albers. 1978. Regulatory role of insulin in the degradation of low density lipoprotein by cultured human skin fibroblasts. Biochim. Biophys. Acta. 529:292-299.

36. Berry, E. M., E. Ziv, H. Bar-on. 1981. Lipoprotein secretion by isolated perfused livers from streptozotocin-diabetic rats. Diabetologia. 21:402-408.

37. Mahley, R. W. 1988. Apolipoprotein E: cholesterol transport protein with expanding role in cell biology. Science (Wash. DC). 240:622-630.

38. Reaven, E. P., and G. M. Reaven. 1974. Mechanisms for development of diabetic hypertriglyceridemia in streptozotocin-treated rats. Effect of diet and duration of insulin deficiency. J. Clin. Invest. 54:1167-1178.

39. Weiland, D., C. E. Mondon, and G. M. Reaven. 1980. Evidence for multiple causality in the development of diabetic hypertriglyceridaemia. Diabetologia. 18:335-340.

40. Reaven, G. M., and C. E. Mondon. 1984. Effect of in vivo plasma insulin levels on the relationship between perfusate free fatty acid concentration and triglyceride secretion by perfused rat livers. Horm. Metabol. Res. 16:230-232.

41. Duerden, J. M., S. M. Bartlett, and G. F. Gibbons. 1989. Regulation of very-low-density-lipoprotein lipid secretion in hepatocyte cultures derived from diabetic animals. Biochem. J. 262:313-319. CA.

42. Coat-A-Count Total $T_{3}$. Diagnostic Products Corporation. Los Angeles,

43. Schall, R. F., Jr., A. S. Fraser, H. W. Hansen, C. W. Kern, and H. J. Tenoso. 1978. A sensitive manual enzyme immunoassay for thyroxine. Clin. Chem. 24:1801-1804. 
44. Han, J. H., C. Stratowa, and W. J. Rutter. 1987. Isolation of full-length putative rat lysophospholipase cDNA using improved methods for mRNA isolation and cDNA cloning. Biochemistry. 26:1617-1625.

45. Demmer, L. A., M. S. Levin, J. Elovson, M. A. Reuben, A. J. Lusis, and J. I. Gordon. 1986. Tissue-specific expression and developmental regulation of the rat apolipoprotein B gene. Proc. Natl. Acad. Sci. USA. 83:8102-8106.

46. Feinberg, A. P., and B. Vogelstein. 1984. A technique for radiolabeling DNA restriction endonuclease fragments to high specific activity. Anal. Biochem. 137:266-267.

47. Fourney, R. M., J. Migakoshi, R. S. Day, III, and M. C. Paterson. 1988. Northern blotting: efficient RNA staining and transfer. Focus (Idaho). 10:5-7.

48. Wahl, G. M., E. Ong, J. Meinkoth, R. Franco, and M. Barinaga. 1981 Transfer and Immobilization of Nucleic Acids to $S$ and $S$ Solid Supports. Schleicher and Schuell, Keene, NH. p. 16.

49. Fisher, E. A., R. D. Carroll, J. A. Cortner, and S. Surrey. 1987. Transcriptional activity of the genes for apoproteins A-I and E in neonatal rat liver. Atherosclerosis. 68:249-253.

50. Gibbs, R. A., P-N. Nguyen, and C. T. Caskey. 1989. Detection of single DNA base differences by competitive oligonucleotide priming. Nucleic Acids Res. 17(7):2437-2448

51. Backus, J. W., M. J. Eagleton, S. G. Harris, C. E. Sparks, J. D. Sparks, and H. C. Smith. 1990. Quantitation of endogenous liver apolipoprotein B mRNA editing. Biochem. Biophys. Res. Commun. 170:513-518.

52. Lux, S. E., K. M. John, and H. B. Brewer, Jr. 1972. Isolation and characterization of apoLp-Gln-II (Apo A-II), a plasma high density apolipoprotein containing two identical polypeptide chains. J. Biol. Chem. 247:7510-7518.

53. Blum, C. B., L. Aron, and R. Sciacca. 1980. Radioimmunoassay studies of human apolipoprotein E. J. Clin. Invest. 66:1240-1250.

54. Sparks, C. E., and J. B. Marsh. 1981. Analysis of lipoprotein apoproteins by SDS-gel filtration column chromatography. J. Lipid Res. 22:514-518.

55. Sparks, J. D., M. Bolognino, P. A. Trax, and C. E. Sparks. 1986. The production and utility of monoclonal antibodies to rat apolipoprotein B lipoproteins. Atherosclerosis. 61:205-211.

56. Fan, H., and S. Penman. 1970. Regulation of protein synthesis in mammalian cells. II. Inhibition of protein synthesis at the level of initiation during mitosis. J. Mol. Biol. 50:655-670.

57. Palmiter, R. D. 1972. Regulation of protein synthesis in chick oviduct. II Modulation of polypeptide elongation and initiation rates by estrogen and progesterone. J. Biol. Chem. 247:6770-6780.

58. Ledford, B. E., and D. F. Davis. 1978. Analysis of translational parameters in cultured cells. Biochim. Biophys. Acta. 519:204-212.

59. Peavy, D. E., J. M. Taylor, and L. S. Jefferson. 1985. Time course of changes in albumin synthesis and mRNA in diabetic and insulin-treated diabetic rats. Am. J. Physiol. 248:E656-E663.

60. Dillmann, W. H. 1988. Diabetes mellitus-induced changes in the concentration of specific mRNAs and proteins. Diabetes Metab. Rev. 4:789-797.

61. Taylor, D. S., H-H. Dahl, J. F. Mercer, A. K. Green, and M. J. Fisher. 1989. The effect of streptozotocin-induced diabetes on phenylalanine hydroxylase expression in rat liver. Biochem. J. 264:185-190.

62. Crepin, K. M., M. I. Darville, L. Hue, and G. G. Rousseau. 1988. Starvation or diabetes decreases the content but not the mRNA of 6-phosphofructo-2-kinase in rat liver. FEBS (Fed. Eur. Biochem. Soc.) Lett. 227:136-140.
63. Peterson, D. T., F. P. Alford, E. P. Reaven, I. Ueyama, and G. M. Reaven 1973. Characteristics of membrane-bound and free hepatic ribosomes from insulin-deficient rats. I. Acute experimental diabetes mellitus. J. Clin. Invest 52:3201-3211.

64. Kimball, S. R., K. E. Flaim, D. E. Peavy, and L. S. Jefferson. 1990. Protein metabolism. In Ellenberg and Rifkin's Diabetes mellitus: Theory and Practice. $\mathrm{H}$

Rifkin and D. Porte, Jr., editors. Elsevier/North Holland, Amsterdam. 41-49.

65. Berry, E. M., E. Ziv, and H. Bar-On. 1980. Protein and glycoprotein synthesis and secretion by the diabetic liver. Diabetologia. 19:535-540.

66. Miller, L. L., D. E. Treat, B. Fridd, and D. Wemett. 1990. Effects of streptozotocin diabetes in the rat on blood levels of ten specific plasma proteins and on their net biosynthesis by the isolated perfused liver. Hepatology. 11:635645.

67. Bostrom, K., M. Wettesten, J. Boren, G. Bondjers, O. Wiklund, and S-O. Olofsson. 1986. Pulse-chase studies of the synthesis and intracellular transport of apolipoprotein B-100 in Hep G2 cells. J. Biol. Chem. 261:13800-13806.

68. Sparks, J. D., C. E. Sparks, A. M. Roncone, and J. M. Amatruda. 1988 Secretion of high and low molecular weight phosphorylated apolipoprotein B by hepatocytes from control and diabetic rats. J. Biol. Chem. 263:5001-5004.

69. Larson, D. E., and B. H. Sells. 1987. The function of proteins that interact with mRNA. Mol. Cell. Biochem. 74:5-15.

70. Smith, H. C., S-R. Kuo, J. W. Backus, S. G. Harris, C. E. Sparks, and J. D. Sparks. 1991. In vitro apolipoprotein B mRNA editing: identification of a $27 \mathrm{~S}$ editing complex. Proc. Natl. Acad. Sci. USA. 88:1489-1493.

71. Howard, B. V. 1987. Lipoprotein metabolism in diabetes mellitus. $J$. Lipid Res. 28:613-628.

72. Steiner, G., F. J. Haynes, G. Yoshino, and M. Vranic. 1984. Hyperinsulinemia and in vivo very-low-density lipoprotein-triglyceride kinetics. Am. J. Physiol. 246:E187-192.

73. Kazumi, T., M. Vranic, H. Bar-On, and G. Steiner. 1986. Portal v peripheral hyperinsulinemia and very low density lipoprotein triglyceride kinetics. $M e$ tab. Clin. Exp. 35:1024-1028.

74. Kazumi, T., M. Vranic, and G. Steiner. 1985. Changes in very low density lipoprotein particle size and production in response to sucrose feeding and hyperinsulinemia. Endocrinology. 117:1145-1150.

75. Duerden, J. M., and G. F. Gibbons. 1988. Secretion and storage of newly synthesized hepatic triacylglycerol fatty acids in vivo and in different nutritional states and in diabetes. Biochem. J. 255:929-935.

76. Bjornsson, O. G., J. M. Duerden, S. M. Bartlett, J. D. Sparks, C. E. Sparks, and G. F. Gibbons. 1992. The role of pancreatic hormones in the regulation of lipid storage, oxidation and secretion in primary cultures of rat hepatocytes. Biochem. J. 281:381-386.

77. Panduro, A., Y-C. Lin-Lee, L. Chan, and D. A. Shafritz. 1990. Transcriptional and posttranscriptional regulation of apolipoprotein E, A-I, and A-II gene expression in normal rat liver and during several pathophysiologic states. Biochemistry. 29:8430-8435.

78. Elshourbagy, N. A., M. S. Boguski, W. S. Liao, L. S. Jefferson, J. I. Gordon, and J. M. Taylor. 1985. Expression of rat apolipoprotein A-IV and A-I genes: mRNA induction during development and in response to glucocorticoids and insulin. Proc. Natl. Acad. Sci. USA. 82:8242-8246.

79. Lin, R. C. 1988. Effects of hormones on apolipoprotein secretion in cultured rat hepatocytes. Metab. Clin. Exp. 37:745-751. 